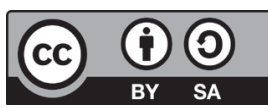

Piotr Łaszczyca

Https://orcid.org/0000-0001-8921-0941

Uniwersytet Śląski w Katowicach

piotr.laszczyca@us.edu.pl

\title{
Śmierć wstydu
}

„Teksty z Ulicy. Zeszyt memetyczny” 2019, nr 20

Https://doi.org/10.31261/tzu.2019.20.04

\section{Streszczenie}

Wstyd i poczucie winy wraz z dumą tworzą system kontroli - „system emocji szacunku/ poważania" (deference-emotion system) - służący ochronie relacji społecznych. Przyczyny wstydu są w znacznym stopniu wyuczone, właściwe dla danej kultury i mogą być traktowane jako zjawisko memetyczne. Przyczyny wstydu często dają się zredukować do odchyleń od kulturowo przyjętej normy lub utraty intymności. Stąd utrata wstydu - społeczna śmierć wstydu - mogą pociągać za sobą niepożądane skutki w funkcjonowaniu jednostek i społeczeństwa.

Neurobiologiczne podstawy wstydu opierają się na teorii umysłu jako funkcji psychicznej właściwej dla człowieka i być może nielicznych gatunków zwierząt. Poszerza ją intencjonalność rozumiana jako zdolność do wielopoziomowego, rekurentnego (łańcuchowego) modelowania stanu umysłu kolejnych osób. Podłożem tych funkcji są obszary wielkiego kręgu kognitywnego mózgowia obejmujące korę przedczołową, obręcz, niektóre obszary kory ciemieniowej, potylicznej i skroniowej oraz wyspę i ciało migdałowate. Wstyd i pokrewne mu poczucie winy objawiają się odmienną aktywnością tych struktur.

We współczesnym społeczeństwie przyczyn śmierci wstydu upatrywać można w czterech hipotetycznych obszarach relacji społecznych, prowizorycznie określając je jako: 1) łatwość i taniość bzdury; 2) demistyfikacja wzorców elitarnych; 3) dewaluacja edukacji i kultury; 4) błąd adresowania przekazu i długie dojrzewanie krytycznej mądrości. Przykładami mogą być powszechnie obserwowane i dyskutowane zjawiska, takie jak: znacznie większa propagacja informacji fałszywej i szkodliwej, lecz za to oddziałującej na emocje; ujawnienie w komunikacji społecznej prawdy o wzorcach kultury elit w powiązaniu z rezygnacją z intymności; obniżenie standardów wymagań w edukacji w związku z jej umasowieniem; prezentację w dziełach sztuki, m.in. filmowej, form, treści i problemów, do których cześć odbiorców nie dojrzała, co skutkuje zmianami wrażliwości i postaw etycznych.

\section{Słowa klucze:}

objawy wstydu, przyczyny wstydu, neurobiologia wstydu, bezwstyd, hipotezy przyczyn bezwstydu 


\section{Death of the shame}

\section{Summary}

Shame and guilt together with pride create a control system - a deference-emotion system - serving to protect social relations. The reasons for shame are to a large extent learned, specific to a given culture and can be regarded as a memetic phenomenon. The causes of shame can often be reduced to deviations from the culturally accepted norm or loss of intimacy. Thus, the loss of shame - the social death of shame - can have undesirable consequences for the functioning of individuals and society.

The neurobiological background of shame is based on the theory of mind as a psychic function proper to man and perhaps a few species of animals. It is expanded by intentionality, understood as the ability to multi-level, recurrent (chain) modelling of the state of mind of subsequent individuals. The basis of these functions are the areas of the large cognitive circuit of the brain including the prefrontal cortex, the cingulum, some areas of the parietal, occipital and temporal cortex and the insula and amygdala. The shame and related guilt reveal themselves in the different activities of these structures. The reasons for the death of shame in modern society can be seen in four hypothetical areas of social relations, provisionally described as: 1) ease and cheapness of nonsense; 2) demystification of elite behavioural patterns; 3) devaluation of education and culture; 4) erroneus addressing the message and long maturation of critical wisdom. Examples are commonly observed and discussed phenomena, such as: much greater propagation of false and harmful information but affecting emotion; revealing in social communication the truth about the cultural patterns of the elite in connection with the resignation from intimacy; lowering the standards of requirements in education due to its easy and mass availability; presentation in works of art, mainly in cinema pictures, forms, contents and problems to which some of the recipients have not been matured, which results in changes in sensitivity and ethical attitudes.

\section{Keywords:}

signs of shame, reasons of shame, neurobiology of shame, immodesty, hypothes on reasonsofthe immodesty

Wstyd - świadoma osobista emocja, relacja społeczna i zjawisko kulturowe - zajmował zwykłych ludzi, myślicieli i badaczy od czasów przedpiśmiennej historii. Opis wstydu, jak równieżi utraty poczucia wstydu,zawarty jest świętych księgach i mitologiach starożytnych. Wstyd leży u podstaw właściwego kulturze europejskiej, starotestementowego pojmowania kondycji ludzkiej i grzechu pierwotnego, gdzie jawi się jako przedstawienie upadku pierwszych ludzi, zabójstwa Abla przez Kaina, zepsucia moralnego ludzkości i zapowiedzi potopu oraz dziejów patriarchy Noego i jego synów ${ }^{1}$.O wstydzie rozprawiali filozofowie, artyści i kapłani: Homer, Arystoteles, Platon, Konfuncjusz ${ }^{2}$, św. Augustyn, św. Tomasz, Alberti ${ }^{3}$, Machia-

1 Biblia Tysiaclecia Online, 2003.

2 Konfuncjusz - 551-479 p.n.e.

3 Leon Battista Alberti (1404-1472) - włoski malarz, poeta, filozof, kartograf, muzyk i architekt, przedstawiciel humanistycznego nurtu włoskiego renesansu. 
velli $^{4}$, Kant, Freud ${ }^{5}$, Nietzsche... aż po Sartre'a ${ }^{6}$ i bioetyków. Ich poglądy są ciągle odswieżanei dyskutowane przez współczesnych autorów ${ }^{7}$. Wstyd stał się obiektem badań społecznych, psychologicznych, behawioralnych i neurobiologicznych, w których istotne miejsce należy się Karolowi Darwinowi ${ }^{8}$.

W życiu wpółczesnych społeczeństw można dostrzec zanik wstydu i szerzenie się bezwstydu, często bardzo odległego od rzymskiej zasady Naturalia non sunt turpia ${ }^{9}$. Nie ma nacji, środowiska lub grupy społecznej, w której nie występowałaby śmierć wstydu - zanik wstydui tryumf prymitywnego bezwstydu. Zdają się temu sprzyjać nowe techniki komunikacji i media elektroniczne. Śmierć wstydu objawia się u polityków, hierarchów koscioła, celebrytów, uczniów... zwykłych ludzi. Wśród „możnych” śmierć wstydu przejawia się mijaniem z prawdą wbrew oczywistym faktom, upublicznionymi ekscesami obyczajowymi, bezczelnymi nadużyciami gospodarczymi i nadużyciem społecznego zaufania oraz unikaniem moralnej ${ }^{10}$ - a nierzadko i karnej - odpowiedzialności. Próba wskazania (łatwo dostępnych w mediach) przykładów, z konieczności, nacechowana byłaby ideologicznie. Często śmierć wstydu polega na odrzuceniu własnej intymności, tożsamym z ekshibicjonizmem psychicznym i seksualnym, zazwyczaj połączonym również z bezgranicznym prymitywizmem, bezrefleksyjnością i agresją. Przykładem moga być niektórzy blogerzy, użytkownicy portali spolecznosciowych i - w skrajnej postaci - tzw. patostreamerzy ${ }^{11}$.

4 Niccolò Machiavelli (1469-1527) - prawnik, filozof, pisarz społeczny i polityczny, historyk i dyplomata florencki, działający w okresie odrodzenia.

5 A.P. Morrison, Working with shame in psychoanalytic treatment, "J Am Psychoanal Assoc." 1984, no 32(3), pp. 479-505.

6 L. Dolezal, Shame, Vulnerability and Belonging: Reconsidering Sartre's Account of Shame, "Human Studies" 2017, no 40(3), pp. 421-438.

7 Ch.C. Raymond, Shame And Virtue In Aristotle, "Oxford Studies in Ancient Philosophy" 2017, no 53, pp. 111-161; doi: 10.1093/oso/9780198815655.003.0004; Ch.C. Raymond, Shame and Virtue in Plato and Aristotle. Dissertation Presented to the Faculty of the Graduate School of The University of Texas at Austin in Partial Fulfillment of the Requirements for the Degree of Doctor of Philosophy, The University of Texas at Austin, May 2013, https://repositories.lib.utexas. edu/handle/2152/25184, pp. 1-151 (http://hdl.handle.net/2152/25184 [dostęp: 3.05.2018]); N. Higgins, Shame on You: The Virtuous Use of Shame in the Aristotle's Nicomachean Ethics, "Expositions", 2015, no 9(2), pp. 1-15; L. Yinghua, The Phenomenology of Shame: A Clarification in Light of Max Scheler and Confucianism. "Continental Philosophy Review" 2018, no 51 (4), pp. 507-525; Wstyd w kulturze 2. Kolokwia polsko-biatoruskie, red. E. Kosowska, G. Kurylenka, A. Gomóła, Katowice 2008 (D. Wężowicz-Ziólkowska, Wstyd a władza (paradygmatów), s. 15-31; A. Gomóła, Przeciw naturze $i$ kulturze. Transseksualizm a wstyd, s. 40-69; A. Budzyńska-Daca, Wstyd - uczucie czy cnota? Dylematy etyki arystotelesowskiej w komentarzach Sebastiana Petrycego z Pilzna, s. 119-130).

${ }^{8}$ Ch. Darwin, The Expression of the Emotions in Man and Animals, chapter 13: Self-Attention, Shame, Shyness, Modesty; Blushing, New York 1872, pp. 309-346. [Content: Nature of a blush -Inheritance -- The parts of the body most affected -- Blushing in the various races of man -- Accompanying gestures -- Confusion of mind -- Causes of blushing -- Self-attention, the fundamental element -- Shyness -Shame, from broken moral laws and conventional rules -- Modesty -- Theory of blushing -- Recapitulation]

9 Przypisywane Eurypidesowi (w tragedii) Hypsipyle (między 409 p.n.e. a 407 p.n.e.). Za: D. Wężowicz-Ziółkowska, Wstyd a wtadza (paradygmatów)..., s. 15-31.

${ }^{10}$ Przeciw - czytamy, jest - pan poset Kurski. Dlaczego Pan ktamat? „Newsweek” 07.09.2017.

${ }_{11}$ Trwa walka z „patostreamerami, http://bialystok.eska.pl/t-patostream-kanaly [dostęp: 16.04.2018]; Patostream - https://pl.wikipedia.org/wiki/Patostream [dostęp: 16.04.2018]. 
Praktycznie zanikła społeczna rola wstydu jako indywidualnej odpowiedzi (reakcji na konflikt) i wyuczonej, społecznie wymuszonej kary za naruszenie tabu kulturowego. Zmieniły się też radykalnie konteksty i preteksty do stosowania wstydu jako przemocy symbolicznej i opresji społecznej. Odeszły w przeszłość niosące zawstydzenie i upokorzenie maski wstydu z metalową imitacją świńskiego ryja, flet wstydu (zamykany na szyi), wysoki stożek coroza zakładany na głowę wraz z podobnym do szkaplerza sambenito (sanbenito), pręgierz lub amputacje cześci twarzy i ciała jako znaki napiętnowania odstępców lub opaska z gwiazdą Dawida. Nowymi symbolami i pretekstami zawstydzenia - szczególnie wśród młodzieży - staje się niemarkowy albo niemodny stroj, sprzęty, gadżety i poglądy ${ }^{12}$. Utraciły moc oddziaływania wyrafinowane metody zawstydzania, apelujące do zdobywania wykształcenia i wysokiej kultury, jak gombrowiczowskie upupianie i przyprawianie gęby wpisane w plakat Papierosy sq do dupy Andrzeja Pagowskiego (1994) lub teatralny plakat Mieczysława Górowskiego do Ferdydurke (1994) ${ }^{13}$.

\section{Waga wstydu}

Brak jednoznacznych analiz danych historycznych i literackich o skali bezwstydupowoduje, że trudno jest ocenić czy bezwstyd narasta współcześnie. Dostępne w powszechnej kulturze zapiski o zakłamaniu, rozwiązłości, obłudzie i pruderii, które charakteryzowały dwory możnych, nie mogą dać statystycznie wiarygodnego świadectwa. Zaciemnia obraz globalizacja i komercjalizacja kultury oraz odejście od typowego dla społeczeństw europejskich przed XXI w. pojmowania wstydu w odniesieniu do etyki chrześcijańskiej i seksualności ${ }^{14}$.

Pytania o wstyd i bezwstyd - śmierć wstydu - stają się istotne dla funkcjonowania współczesnych społeczeństw. Wstyd jest bowiem behawioralnym, wrodzonym mechanizmem regulującym interakcje społeczne jednostki i zapobiegającym zachowaniom skierowanym przeciw wspólnocie. Thomas J. Scheff stwierdza, że wstyd i poczucie winy wraz z dumą tworzą system kontroli społecznej - „system emocji szacunku/poważania” (deference-emotion system) ${ }^{15}$. Jest to ewolucyjny „mechanizm przetrwania” związków społecznych i „ochrona przyjaźni”16. Inten-

12 Coroza, sanbenito i inne... - odpowiednie hasła wikipedyczne jako ilustracja [dostęp: 16.04.2018].

${ }^{13}$ Gęba a twarz i pupizm - www.gombrowicz.net [dostęp: 16.04.2018].

14 D. Wężowicz-Ziółkowska. Wstyd a wtadza (paradygmatów)..., 15-31.

15 Th.J. Scheff, When Shame Gets Out of Hand. [https://www.sagepub.com/sites/default/ files/upm-binaries/13294_Chapter_5_Web_Byte_Thomas_J_Scheff.pdf. za oryg. Thomas J. Scheff, Socialization of emotions: Pride and shame as causal agents, [in:] Research Agendas in the Sociology of Emotions, ed. T. Kemper, New York 1990, pp. 283; Th.J. Scheff, Shame and conformity: The deference-emotion system, „American Sociological Review” 1988, 53(3):395-406.

16 R. O'Hare, Shame isn't necessarily a bad thing! Emotion evolved as a 'survival mechanism' to protect us from damaging friendships., "DailyMail", 2 March 2016; D. Sznycer, J. Tooby, L. Cosmides, R. Porat, Sh. Shalvi, E. Halperin, Shame closely tracks the threat of devaluation by others, even across cultures, "Proceedings of the National Academy of Sciences" 2016, 113(10): 201514699 ; DOI: 10.1073/pnas.1514699113. 
sywność wstydu i podatność na wstyd jest proporcjonalna do ścisłości związków interpersonalnych podmiotu z grupą i zależna od kultury (np. w Japonii i Indiach $\mathrm{w}$ innym nasileniu i formach niżw USA, Wielkiej Brytanii) ${ }^{17}$.

\section{Podłoże i mechanizm}

Objawy wstydu są podświadomą, niechcianą i z reguły skrywaną ${ }^{18}$ reakcją zawstydzonej osoby. Zazwyczajsa jednak intuicyjnie odbierane przez obserwatorów ${ }^{19}$. Na objawy wstydu („the shame code”) składają się napięcie mięśni ciała twarzy, zachowania ukrywajace, takie jak znieruchomienie (zamarcie w bezruchu), prowadzące do skulenia - zgarbienia się i pochylenia głowy, ukrywanie się i unikanie kontaktu wzrokowego, niepokój ruchowy - wiercenie się, oblizywanie lub przygryzanie warg, marszczenie i niepokój dochodzący do stanu roztrzęsienia - paniki. Charakterystyczne są też objawy wegetatywne zdenerwowania (w tym zmiany ukrwienia skóry twarzy - bladość lub zarumienienie (blushing) - i potliwość emocjonalna). Wśród behawioralnych objawów zdarza się nasilona ekspresja słowna lub milczenie połączone z brakiem pewności siebie, lękiem przed oceną ${ }^{20}$ i poczuciem niskiej wartości, izolowaniem się, niezdolnością do uczenia się, nieprofesjonalnym zachowaniem i zaburzoną zdolnością empatii, a także z oczekiwaniem pomocy i skłonnością do podporządkowania się ${ }^{21}$. Znamienne są także językowe objawy wstydu: treściowe, werbalne i prozodyczne. Należy do nich używanie słownictwa wskazującego na poczucie zranienia, upokorzenia i wykluczenia, wyrażeń ujawniających negatywną samoocenę lub w niektórych przypadkach wskazujących na wypieranie problemu i racjonalizację, jako mechanizm obronny. Ten ostatni aspekt może objawiać się powściągliwością, obojętnością, oszołomieniem, pustką myślową i emocjonalną, niezdawaniem sobie sprawy z sytuacji ${ }^{22}$. Treść wypowiedzi może być fragmentaryczna, niespójna, z częstymi zmianami wątku. Prozodyczne (paraprozodyczne) objawy wstydu obejmują nieregularny, rwany rytm wypowiedzi z pauzami i niewerbalnymi przerywnikami (wykrzyknikami emotywnymi), jąkaniem i perseweracjami treściowymi, czasami może pojawiać się także fałszywy - maskujący - śmiech lub uśmiech ${ }^{23}$. Bezwstyd wiąże się z brakiem tych objawów, za to z objawami zbliżonymi do nadaktywności w stanach

${ }^{17}$ D. Sznycer, J.Tooby, L. Cosmides, R. Porat, Sh. Shalvi, E. Halperin, Shame closely tracks...

18 A. Błachnio, Identyfikacja wstydu. „Studia z psychologii w KUL” 2005, t. 12, s. 12-28.

19 Ch. Darwin, The Expression of the Emotions in Man and Animals...

20 Tamże; A. Błachnio, Identyfikacja wstydu....; K. De France, D.Lanteigne, J. Glozman, T. Hollenstain, A New Measure of the Expression of Shame: The Shame Code, "Journal of Child \& Family Studies" 2017, 26(3), pp. 769-780.

21 W.E. Bynum, A.R. Artino, S. Uijtdehaage, A.M.B. Webb, L. Varpio, Sentinel Emotional Events: The Nature, Triggers, and Effects of Shame Experiences in Medical Residents. "Acad Med." 2019, no 94(1), pp. 85-93.

22 S.M. Retzinger, Identifying Shame and Anger in Discourse. "American Behavioral Scientist" 1995, no 38(8), 1104-1113; A. Błachnio, Identyfikacja wstydu...

${ }^{23}$ A. Błachnio, Identyfikacja wstydu... 
pobudzenia maniakalnego i paranoicznego, często towarzyszącym publicznym sukcesom i - w konsekwencji - ekscesom.

Wstyd można charakteryzować jako zjawisko memetyczne - związane z przekazem informacji ${ }^{24}$, treścią i formą komunikacji, jej aspektem językowym lub zachowaniami publicznymi. Zatem i bezwstyd musi należeć do tej kategorii i być promowany przez (m.in. medialne) nasilenie informacji - memów związanych z nieprawdą, kłamstwem, manipulacją, uproszczeniem. Wydaje się regułą, że powodem wstydu jest odstępstwo od kulturowo przyjętej normy i subiektywnego poczucia normalności - w praktyce, od najczęstszych w danej społeczności form zachowań i komunikacji. Nader często wiąże się to z utratą intymności i obnażeniem² ${ }^{25}$. Kulturowa zmienność („ewolucja”) przyczyn wstydu wskazuje na istotność uczenia się odpowiednich norm. Stosunkowo banalnym przykładem jest tu wstyd związany z nagością i czynnościami fizjologicznymi, mający także wyraz w sztuce „wysokiej”26.

Banalną konkluzja jest zatem, że wstyd i bezwstyd muszą opierać się na interakcjach społecznych. Niebanalną konsekwencją tego stwierdzenia może być zaś hipoteza, że wzbudzenie poczucia wstydu i jego intensywność zależeć mogą od wielkości grupy, do której należy osoba prezentująca wstydliwe formy zachowania, a także wielkość grupy będącej odbiorcą - obserwatorem tych zachowań. Zapewne można tu poszukiwać relacji z liczbami Dunbara ${ }^{27}$ jako jedną z miar odległości osób wchodzących w interakcje wstydu ${ }^{28}$. Egzemplifikacją i modelem tych relacji mogłyby być portale społecznościowe typu Facebook i programy medialne o formule podobnej do Big Brothera.

Funkcje kognitywne i procesy psychologiczne leżące u podstaw wstydu obejmują świadomość, teorię umysłu i pojmowaną biologicznie intencjonalność, co najmniej drugiego rzędu. Koncepcję Teorii Umysłu (mentalizacja, Theory of Mind, ToM $)^{29}$ rozumianej jako zdolność do wnioskowania o stanach mentalnych

24 P. Łaszczyca, Memy w pamięci: jak wyśledzić memy w mózgu, „Teksty z ulicy. Zeszyt memetyczny" 2017, nr 18, s. 11-42.

25 A. Młynarska-Jurczuk, Wstyd jako emocja ucieleśniona - twarz, ciato $i$ role ptciowe w procesie społecznej konstrukcji wstydu. „Dyskursy Młodych Andragogów (Zielona Góra)” 2016, nr 17, s. $367-369$.

26 Np. Marcel Duchamp, Fontanna, 1917; Katarzyna Kozyra, Olimpia, 1996; Gustave Courbet, L'Origine du monde, 1866; Piero Manzoni, Merda d'artista, 1961; Leszek Żegalski, Epizod bitewny czyli sraczka samuraja" (1986), olej z cyklu Wspótczesny rycerz.

${ }_{27}$ Dunbar's number - Wikipedia: https://en.wikipedia.org/wiki/Dunbar\%27s_number [dostęp: 20.01.2019]; warto zwrocić uwagę, że - niezależnie od uwag krytycznych wzgledem koncepcji - liczby te zaczynają się od 1,5 i rosną w przyblizeniu jako ciag kolejnych wyników mnożenia przez 3: 1,5; 5; 15; 50; 150; 500; 1 500; ...itd.; R.A. Hill, R.I.M. Dunbar, Social network size in humans, "Human Nature" 2003, no 14 (1), pp. 53-72; R.I.M. Dunbar, Ilu przyjaciót potrzebuje cztowiek? Liczba Dunbara i inne wybryki ewolucji, przeł. D. Cieśla-Szymańska, Kraków 2019.

28 Small World Experiment - Wikipedia: https://en.wikipedia.org/wiki/Small-world_ experiment (Small Word Theory) [dostęp: 20.01.2019].

29 W zakresie ToM wyróżnia się dwa rejestry: kognitywną ToM i emocjonalną (symulacyjną) ToM związane $\mathrm{z}$ rozpoznawaniem odmiennych czynności mentalnych: poznawczych i emocjonalnych. Dwie dominujace hipotezy opisujace mechanizm ToM to: Teoria Teorii („dziecka naukowca-obserwatora i testera teorii ad hoc”) oraz Teoria Symulacji - „projekcji 
(czytania myśli) innych osobników (ludzi), wprowadzili w 1978 roku David Premack i Guy Woodroff ${ }^{30}$ rozwijał zaś m.in. Simon Baron-Cohen ${ }^{31}$. Biologiczna koncepcja intencjonalności jest rozwinięciem ToM na kolejne poziomy (rzędy) modelowania stanu umysłu przez kolejne spostrzegające się (łańcuchowo) osoby (osobniki): ,jak dany osobnik odczytuje/wyobraża sobie stan umysłu obserwowanego osobnika na temat stanu umysłu kolejnego osobnika"32. Posiadanie teorii umysłu (i intencjonalności) winno pozostawać wzwiązku ze zdolnością do empatii, co implikuje krytyczne odwołanie się do koncepcji neuronów lustrzanych ${ }^{33}$. Paradoksalnie, jeśli przyjąć, że osoby ze spektrum autyzmu mają upośledzone zdolności rozumienia stanów mentalnych innych osób, można by oczekiwać u nich braku objawów wstydu. Intrygujący jest też problem wstydu u innych gatunków, które przejawiają objawy empatii, sugerujący możliwość posiadania przez nie teorii umysłu ${ }^{34}$.

\section{Emocja}

Wstyd charakteryzowany jest w psychologicznych koncepcjach emocji, począwszy od koncepcji wymiarów emocji Wilhelma Wundta (1899), poprzez kołowy model emocji (circumplex model of affect) Jamesa A. Russela $(1980)^{35}$, jako jedna z 10 emocji podstawowych wg Caroll Izard ${ }^{36}$, po psychoewolucyjną koncepcję koła (diad) emocji Roberta Plutchika (1960-1980) ${ }^{37}$. Model koła emocji Roberta Plutchika

własnych znanych stanów na stany mentalne innych". Por.: Wikipedia [eng.].

30 D. Premack, G. Woodruff, Does the chimpanzee have a theory of mind? "Behavioral and Brain Sciences" 1978, 1(4), pp. 515-526.

31 S. Baron-Cohen, A.M. Leslie, U. Frith, Does the autistic child have a theory of mind?, "Cognition" 1985, no 21(1), pp. 37-46; S. Baron-Cohen, Precursors to a theory of mind: Understanding attention in others, (in) Natural theories of mind: evolution, development, and simulation of everyday mindreading, ed. A. Whiten, Oxford, UK Cambridge, Massachusetts: 1991, pp. 233-251.

32 R.I.M. Dunbar, Nowa historia ewolucji cztowieka, przeł. B. Kowalczyk, Kraków, 2013; Ł. Kwiatek, Intencjonalność, czyli co odróżnia Szekspira od szympansa. „GraniceNauki.pl” (on line) [dostęp: 09.07.2013]; https://www.granicenauki.pl/intencjonalnosc-czyli-co-odrozniaszekspira-od-szympansa-25965.

33 J. Dvash, S.G. Shamay-Tsoory, Theory of Mind and Empathy as Multidimensional Constructs. Neurological Foundations. "Top Lang Disorders" 2014, no 34(4), pp. 282-295; C. Ch. Woodruff, Reflections Of Others And Of Self: The Mirror Neuron System's Relationship To Empathy. Chapter 6. (in) The Neuroscience of Empathy, Compassion, and Self-Compassion, Elsevier, 2018, pp. 157-187; G. Hickok, Mit neuronów lustrzanych, przeł. A. Machniak, K. Cipora, Kraków 2016; D. Zahavi, Self, consciousness, and shame. (in) The Oxford Handbook of Contemporary Phenomenology, New York 2012.

34 F.B.M. de Waal, Commiserating Mice, "Scientific American" 24 June 2007; M. Bekoff, Can Dogs Experience Guilt, Pride, and Shame: Why Not?" PsychologyToday”, 2013; F.B.M. de Waal, Wiek empatii. Jak natura uczy nas życzliwości, przeł. Ł. Lamża, Kraków 2019.

35 J.A. Russell, A circumplex model of affect, "Journal of Personality and Social Psychology" 1980, no 39(6), pp. 1161-1178; J. Posner, J.A. Russell, B.S. Peterson, The circumplex model of affect: An integrative approach to affective neuroscience, cognitive development, and psychopathology, "Dev Psychopathol" 2005, no 17(3), pp. 715-734.

36 C.E. Izard, Emotion Theory and Research: Highlights, Unanswered Questions, and Emerging Issues, "Annu Rev Psychol." 2009, no 60, pp. 1-25.

37 Theory of emotion - https://en.wikipedia.org/wiki/Emotion [dostęp: 05.01.2019]; R. Plutchik, 
(1980, 1984) zakłada istnienie ośmiu podstawowych emocji wrodzonych, które tworzą cztery pary przeciwieństw:

radość - smutek (joy - sadness),

strach - gniew (fear - anger),

zdziwienie/zaskoczenie - oczekiwanie/przewidywanie (surprise - anticipation),

akceptacja/ufność - wstręt/niechęć (trust - disgust).

Ich kombinacje z kolei tworzą dwadzieścia cztery emocje złożone, jako pierwszo-, drugo-i trzeciorzędowe diady emocji podstawowych, zróżnicowane dodatkowo pod względem intensywności. Wstyd jest trzeciorzędową diadą emocji: strachu i odrazy (fear + disgust). Wzmacnia (negatywnie) zachowanie i cechuje percepowaną rzeczywistość. Jego przeciwstawieniem jest duma i pycha (diada drugorzędowa radości i gniewu: joy + anger). Bliska pod względem behawioralnym wstydowi jest drugorzędowa emocja poczucia winy tworzona przez radość i strach $($ joy + fear $)$.

Tabela 1: Emocje złożone (24) i emocje podstawowe, jako ich składniki (8) wg teorii emocji Roberta Plutchika (1960-1980) (kolejność zmodyfikowana, tłum. własne, źródło: Teoria emocji Plutchika - https://pl.wikipedia.org/wiki/Teoria _emocji_Plutchika (dostęp: 2019-01-18)'

\begin{tabular}{|c|c|c|c|}
\hline $\begin{array}{l}\text { Podstawowe diady } \\
\text { (często odczuwalne) }\end{array}$ & $\begin{array}{l}\text { Drugorzędne diady } \\
\text { (czasami } \\
\text { odczuwalne) }\end{array}$ & $\begin{array}{l}\text { Trzeciorzędne diady } \\
\text { (rzadziej odczuwalne) }\end{array}$ & $\begin{array}{l}\text { Przeciwieństwa } \\
\text { (wykluczające się) }\end{array}$ \\
\hline $\begin{array}{l}\text { radośćtzaufanie } \\
\rightarrow \text { miłość }\end{array}$ & $\begin{array}{l}\text { radość + strach } \\
\rightarrow \text { poczucie winy }\end{array}$ & $\begin{array}{l}\text { radość + zaskoczenie } \\
\rightarrow \text { zachwyt }\end{array}$ & $\begin{array}{l}\text { radość + smutek } \\
\rightarrow \text { konflikt }\end{array}$ \\
\hline $\begin{array}{l}\text { zaufanie + strach } \\
\rightarrow \text { uległość }\end{array}$ & $\begin{array}{l}\text { zaufanie }+ \\
\text { zaskoczenie } \\
\rightarrow \text { ciekawość }\end{array}$ & $\begin{array}{l}\text { zaufanie + smutek } \\
\rightarrow \text { sentymentalizm }\end{array}$ & $\begin{array}{l}\text { zaufanie + wstręt } \\
\rightarrow \text { konflikt }\end{array}$ \\
\hline $\begin{array}{l}\text { strach + zaskoczenie } \\
\rightarrow \text { poruszenie }\end{array}$ & $\begin{array}{l}\text { strach }+ \text { smutek } \\
\rightarrow \text { rozpacz }\end{array}$ & $\begin{array}{l}\text { strach + wstręt } \\
\rightarrow \text { wstyd }\end{array}$ & $\begin{array}{l}\text { strach + gniew } \\
\rightarrow \text { konflikt }\end{array}$ \\
\hline $\begin{array}{l}\text { zaskoczenie }+ \text { smutek } \\
\rightarrow \text { rozczarowanie }\end{array}$ & $\begin{array}{l}\text { zaskoczenie + wstręt } \\
\rightarrow \text { szok }\end{array}$ & $\begin{array}{l}\text { zaskoczenie + gniew } \\
\rightarrow \text { oburzenie }\end{array}$ & $\begin{array}{l}\text { zaskoczenie }+ \\
\text { przeczucie } \\
\rightarrow \text { konflikt }\end{array}$ \\
\hline $\begin{array}{l}\text { smutek + wstręt } \\
\rightarrow \text { żal }\end{array}$ & $\begin{array}{l}\text { smutek + gniew } \\
\rightarrow \text { cierpienie }\end{array}$ & $\begin{array}{l}\text { smutek }+ \text { przeczucie } \\
\rightarrow \text { pesymizm }\end{array}$ & - \\
\hline $\begin{array}{l}\text { wstręt + gniew } \\
\rightarrow \text { zawiść }\end{array}$ & $\begin{array}{l}\text { wstręt }+ \text { przeczucie } \\
\rightarrow \text { cynizm }\end{array}$ & $\begin{array}{l}\text { wstręt + radość } \\
\rightarrow \text { patologiczna } \\
\text { fascynacja }\end{array}$ & - \\
\hline $\begin{array}{l}\text { gniew + przeczucie } \\
\rightarrow \text { agresja }\end{array}$ & $\begin{array}{l}\text { gniew + radość } \\
\rightarrow \text { duma }\end{array}$ & $\begin{array}{l}\text { gniew + zaufanie } \\
\rightarrow \text { dominacja }\end{array}$ & - \\
\hline $\begin{array}{l}\text { przeczucie + radość } \\
\rightarrow \text { optymizm }\end{array}$ & $\begin{array}{l}\text { przeczucie } \\
+ \text { zaufanie } \\
\rightarrow \text { fatalizm }\end{array}$ & $\begin{array}{l}\text { przeczucie + strach } \\
\rightarrow \text { lęk }\end{array}$ & - \\
\hline
\end{tabular}

The Nature of Emotions: Human emotions have deep evolutionary roots, a fact that may explain their complexity and provide tools for clinical practice, "American Scientist" 2001, no 89(4), pp. 344-350. 


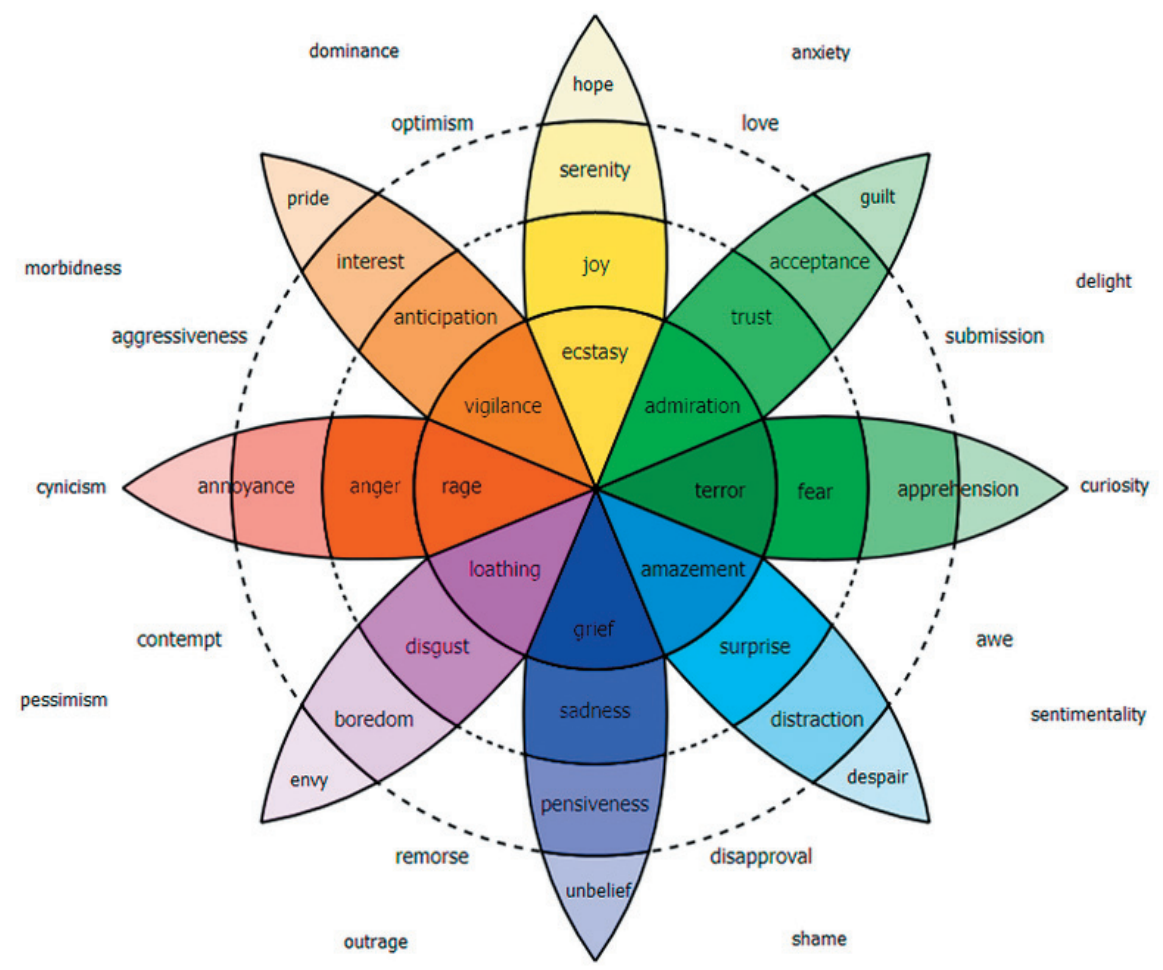

Ryc. 1. Koło emocji Plutchika (właściwie rozeta) obrazujące położenie wstydu (shame), jako emocji trzeciorzędowej,będącej połączeniem pierwotnych emocji strachu i wstrętu (fear + disgust). Koło (rozeta) powstaje w wyniku rozłożenia stożka, którego podstawa jest centralne koło a szczyt odpowiada punktowi zbiegu ośmiu „płatków” (Źródło: Radialny diagram Roberta Plutchika opisujacy strukturę emocji podstawowych i ich pierwszych pochodnych. Https://pl.wikipedia.org/wiki/Plik:Kolo_emocji_plutchika.gif, Rycina oryginalna: Nature of Emiotions by Plutchik. Http://www.fractal.org/Bewustzijns-Besturings-Model/Nature-of-emotions.htm. Autor: Robert Plutchik (dostęp: 2019-01-18).

\section{Chemia, struktura i różnice}

Neurochemiczny model emocji zaproponowany przez Lövheima (2012) ${ }^{38}$ opisuje emocje jako oparte na interakcji trzech systemów jednolitej transmisji synaptycznej. Systemy te tworzą grupy nielicznych neuronów zlokalizowanych podkorowo - w pniu mózgu, działających na rozległe struktury mózgowia. Każda grupa, jako główny mediator, wydziela w synapsach neuronów dopaminę (DA), noradreanalinę (NA) lub serotoninę (5-HT). Systemowi temu przypisuje się główną rolę w tworzeniu emocji i motywacji. Na te neurony działa też znaczna cześć psychofarmaceutyków, narkotyków i dopalaczy.

38 H. Lövheim, A new three-dimensional model for emotions and monoamine neurotransmitters, "Med Hypotheses" 2012, no 70, pp. 341-348. 


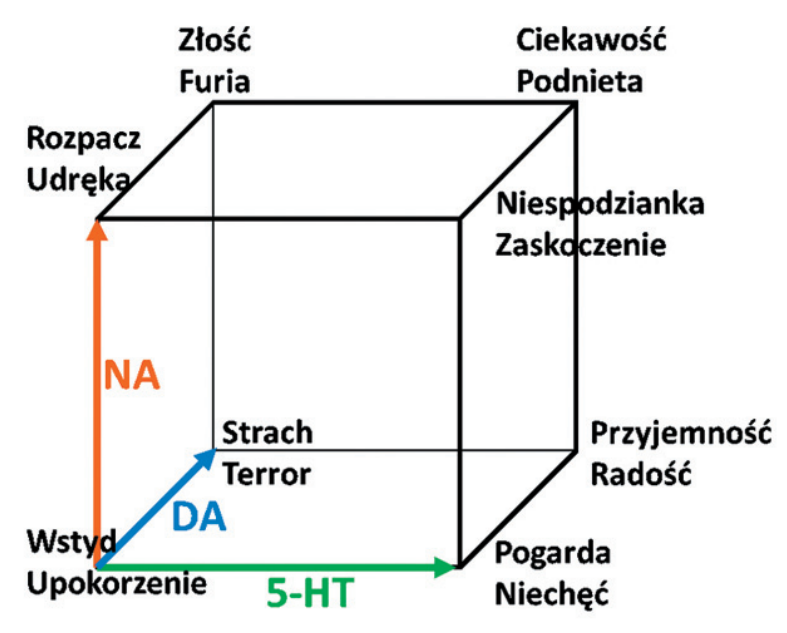

Ryc. 2. Neurochemiczny model emocji L Lövheima uwzględniający interakcje trzech systemów jednolitej transmisji chemicznej w mózgowiu (dopaminowego - DA, noradrenalinowego - NA i serotoninowego - 5-HT). Źródło - zmod. na podst. H. Lövheim, A new three-dimensional model...

Tabela 2. Neurochemiczny model emocji Lövheima obrazujący zmiany aktywności w trzech systemach jednolitej transmisji chemicznej w mózgowiu (dopaminowym - DA, noradrenalinowym - NA, i serotoninowym - 5-HT); $\swarrow^{\swarrow}$ obniżenie, ${ }^{\nearrow}-$ zwiększenie $^{-}$ aktywności systemu. Źródło - zmod. na podst. H. Lövheim, A new three-dimensional model...

\begin{tabular}{|l|l|l|l|}
\hline Emocje podstawowe & 5-HT & DA & NA \\
\hline wstyd/upokorzenie & $\swarrow$ & $\swarrow$ & $\swarrow$ \\
\hline rozpacz/udręka & $\swarrow$ & $\swarrow$ & $\nearrow$ \\
\hline strach/terror & $\swarrow$ & $\nearrow$ & $\swarrow$ \\
\hline złość/furia & $\swarrow$ & $\nearrow$ & $\nearrow$ \\
\hline pogarda/niechęć & $\nearrow$ & $\swarrow$ & $\swarrow$ \\
\hline niespodzianka/zaskoczenie & $\nearrow$ & $\swarrow$ & $\nearrow$ \\
\hline przyjemnośćradość & $\nearrow$ & $\nearrow$ & $\swarrow$ \\
\hline ciekawość/podnieta & $\nearrow$ & $\nearrow$ & $\nearrow$ \\
\hline
\end{tabular}

Relacje między wstydem (shame), pychą (hubris), dumą (pride) i poczuciem winy (guilt) są często rozważane w badaniach i literaturze ${ }^{39}$

39 B. Danieluk, Konceptualizacja poczucia winy $i$ wstydu w ujeciu poznawczym $i$ spotecznym, „Annales Universitatis Mariae Curie-Skłodowska, Lublin - Polonia”, vol. XIX, Sectio J, 2006. s. 71-86. 
Tabela 3. Strukturalny model wywoływania ewaluacyjnych emocji samoświadomościowych $^{40}$ (za M.Lewis, J.M. Haviland-Jones, Psychologia emocji, przeł. M. Kacmajor i in., Gdańsk 2005, s. 765).

\begin{tabular}{|l|l|l|}
\hline Sukces & Porażka & Rodzaj autoatrybucji \\
\hline pycha & wstyd & całościowa \\
\hline duma & poczucie winy & częściowa \\
\hline
\end{tabular}

Tabela 4. Porównanie wstydu i poczucia winy ${ }^{41}$.

\begin{tabular}{|l|l|}
\hline Wstyd & Poczucie winy \\
\hline zogniskowany na samym sobie & zogniskowany na czynie raniącym innych \\
\hline poczucie zła w byciu sobą & poczucie zła w dokonanym czynie \\
\hline pytanie jak ja mogłem to zrobić & pytania jak to mogłem zrobić \\
\hline uczucie silnego dysstresu i niewłaściwości & uczucie bólu \\
\hline brak poczucia kontroli nad następstwami & poczucie kontroli nad następstwami \\
\hline pragnienie ucieczki, skurczenia, unikania & napięcie i skrucha \\
\hline motywacja do ukrycia lub ataku na siebie/innych & motywacja do naprawy szkód, poprawy \\
\hline obciążanie innych, szukanie kozła ofiarnego & branie osobistej odpowiedzialności \\
\hline
\end{tabular}

Metodami neurobrazowania czynnościowego (fMRI-BOLD) zaobserwowano aktywność neuronalną związaną z emocjami wstydu i winy w obszarach wielkiego kręgu kognitywnego ${ }^{42}$. Obszary te składają się ze struktur mózgowych odpowiedzialnych m.in. za ToM, intencjonalność, empatię i uwagę. Obejmują one ${ }^{43}$ :

- w płacie potylicznym, ciemieniowym i skroniowym: górny zakręt skroniowy (STG), skrzyżowanie skroniowo-ciemieniowe (TPJ), płacik ciemieniowy dolny (IPL), bruzdę skroniową górną (STS), przedklinek (PCun), biegun (czołowy) płata skroniowego (TP);

- zakręt obręczy (CG) w tym: przednią część zakrętu obręczy (ACC), tylny zakręt obręczy (PCC/PrCC);

- $\quad$ korę przedczołową, w tym: korę oczodołowo - czołową (OFC), brzuszną

${ }_{40}$ M. Lewis, J.M. Haviland-Jones, Psychologia emocji, przeł. M. Kacmajor i in., Gdańsk 2005, s. 765 .

${ }_{41}$ M. Miceli, Ch. Castelfranchi, Reconsidering the Differences Between Shame and Guilt, "Europe's Journal of Psychology" 2018, ejop.psychopen.eu, pp. 1841-0413.

42 J. Kozloski, Closed-Loop Brain Model of Neocortical Information-Based Exchange, "Front. Neuroanat." 2016; http://dx.doi.org/10.3389/fnana.2016.00003.

43 J.J. Dvash, S.G. Shamay-Tsoory, Theory of Mind and Empathy as Multidimensional Constructs. Neurological Foundations, "Top Lang Disorders" 2015, no 34(4), pp. 282-295; J.J. Genga, S. Vossel, Re-evaluating the role of TPJ in attentional control: Contextual updating? "Neuroscience and Biobehavioral Reviews" 2013, no 37, pp. 2608-2620. 
i grzbietową przyśrodkową korę przedczołową (vMPFC i DMPFC), grzbietową i dolną boczną korę przedczołową (DLPFC, IL'P'FC);

- $\quad$ ciało migdałowate i ciało prążkowane.

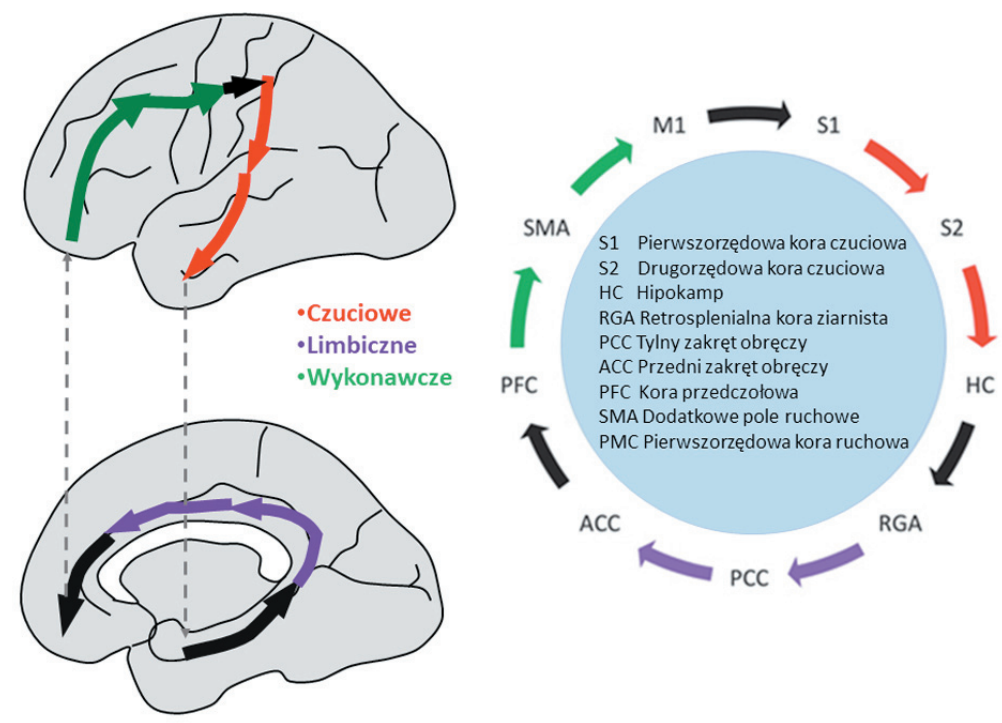

Ryc. 3. Neokortykalna pętla wymiany informacji wg. Jamesa Kozlowskiego: S1, S2 - kora somatosensoryczna pierwszo- i drugorzędowa, HC - hipokamp, RGA - kora retrosplenialna ziarnista, PCC - tylny zakręt obręczy, ACC - przedni zakręt obręczy, PFC - kora przedczołowa, SMA - dodatkowe pole ruchowe, M1 - kora ruchowa pierwszorzedowa.(zmod. za J. Kozlowski, Closed loop brain model...).

Badania różnicowe aktywności tych obszarów w sytuacji kontrolnej oraz w sytuacji wstydu lub winy wykazały, że $\mathrm{e}^{44}$ :

- $\quad$ wstyd aktywuje głównie przedni zakręt obręczy (ACC), zakręt parahipokampalny (PHG), środkowy i dolny zakręt czołowy (MFG i IFG);

- $\quad$ poczucie winy wiąże się z aktywacją zakrętu wrzecionowatego (FG), środkowego zakrętu skroniowego (MTG), wyspy (I) i ciała migdałowatego (A).

We wzorcu aktywacji występują różnice związane z płcią: u kobiet - przewaga aktywacji okolic skroniowych, u mężczyzn - przewaga aktywacji okolic czołowych, potylicznych i ciała migdałowatego.

Brak wstydu jest cechą spajająca dziewięć innych cech diagnostycznych osobowości narcystycznej (narcissistic personality disorder, DSM-5 [2013]) ${ }^{45}$

44 P. Michl, Th. Meindl, F. Meister, Ch. Born, R.R. Engel., M. Reiser, K. Hennig-Fast, Neurobiological underpinnings of shame and guilt: a pilot fMRI study. SCAN 214, 9, 150-157; E. Pulcu, K. Lythe, R. Elliott, S. Green, J.W. Moll, J.F. Deakin, R. Zahn, Increased Amygdala Response to Shame in Remitted Major Depressive Disorder, "PLoS ONE" 2014, no 9(1): e86900.

45 M. Zaslav, Narcissism: The Shame-Negating Personality, "The Neuropsychoterapist" 2017, no $5(2)$, pp. 17-18. 
i objawem towarzyszącym zaburzeniom psychicznym, psychopatii i socjopatii ${ }^{46}$. Niesłuszne jednak byłoby diagnozowanie w tych kategoriach wszystkich zachowań pozbawionych wstydu. Wydaje się, że kontekst życiowy braku wstydu często wiąże się z wiekiem i zasobnością materialną. To, co jest wstydem dla osoby ubogiej, niekoniecznie jest powodem wstydu dla osób zamożnych: „wstyd biedaka - pycha bogatego"47. Co więcej, wywoływanie wstydu może być metodą opresji i sterowania osobami słabszymi w relacjach społecznych. W szerszych relacjach, deprawacja i bezwstyd mogą służyć jako narzędzie zerwania związków społecznych i ubezwłasnowolnienia społeczeństwa ${ }^{48}$. Skrajnego przykładu dostarcza bogata literatura opisująca uwięzienie w obozach koncentracyjnych, łagrach i zwykłych więzieniach $^{49}$, włączając w to słynny eksperyment więzienny Philipa Zimbardo ${ }^{50}$.

Silnym czynnikiem modulujaccym uczucie wstydu i objawy empatii jest stres i presja czasowa, co obrazuje np. katastrofa Titanica i storpedowanie Lusitanii ${ }^{51}$. Dane sugerują, że gdy - jak to miało miejsce na Titanicu - czas i relacje towarzyskie pozwalały na namysł, mężczyznom nie wypadało bezwględnie walczyć o życie kosztem kobiet i dzieci.

\section{Przyczyny wstydu}

Śmierć wstydu - bezwstyd - polega na braku reakcji na typowe bodźce wywołujące wstyd. W źródłach internetowych można znaleźć dziennikarskie lub blogerskie próby zidentyfikowania i wyliczenia przyczyn wstydu ${ }^{52}$, w tym również wyniki badań ankietowych i wypowiedzi naukowców ${ }^{53}$.

46 P. Muris, C. Meesters, J. Heijmans, S. van Hulten, L. Kaanen, B. Oerlemans, T. Stikkelbroeck, T. Tielemans, Lack of guilt, guilt, and shame: a multi informant study on the relations between self conscious emotions and psychopathology in clinically referred children and adolescents, "Eur Child Adolesc Psychiatry" 2016, no 25, pp. 383-396; L. Leedom, Sociopaths and Psychopaths: Have you no shame? (sci - med-blog) lovefraud.com; 2007, https://lovefraud.com/sociopathsand-psychopaths-have-you-no-shame/ [dostęp: 05.01.2019].

${ }_{47}$ Warto rozważyć ten problem np. w odniesieniu do stroju i mód, diety, być może również seksualności.

48 Przykładu dostarczą totalitaryzmy i populizm.

49 V.E. Frankl, Cztowiek w poszukiwaniu sensu, przeł. A. Wolnicka, Warszawa 2018; Abu Ghraib torture and prisoner abuse - https://en.wikipedia.org/wiki/Abu_Ghraib_torture_and_ prisoner_abuse [dostęp 12.07.2019].

50 P. Zimbardo, C. Haney, W.C. Banks., D. Jaffe, The Stanford prison experiment. (Report), 1971; https://web.stanford.edu/dept/spec_coll/uarch/exhibits/Narration.pdf; [dostęp 12.07.2019].

51 M. Mahony, Titanic vs. Lusitania: Time Determined Who Survived. "LiveScience" 2010, March 01; https://www.livescience.com/10953-titanic-lusitania-time-determinedsurvived.html[dostęp 12.07.2019]; także: Titanic vs. Lusitania. Who survived and why, http:// www.smithsonianmag.com/science-nature/titanic-vs-lusitania-who-survived-and-why24622866/\#CmSsRx1wXjS1jVuO.99 [dostęp 12.07.2019].

${ }^{52}$ Najbardziej wstydliwe pytania jakie macie w glowie - https://m-forum.pl/topic/48811najbardziej-wstydliwe-pytania-jakie-macie-w-glowie/; dostęp: 2019-01-20; Czego sie wstydzimy? 10 gtównych powodów do wstydu. - http://tupacz.com/2013/01/czego-sie-wstydzimy-10-glownychpowodow-do-wstydu ; dostęp: 2019-01-20; M. Grudniewska, Z czego sa dumni i czego sie wstydza czytelnicy Wyborczej. „Gazeta Wyborcza”, 16 maja 2018.

53 Piersi, penis, zdrada? Nie, Polacy wstydza sie... „Fakt”, 24 kwietnia 2013, wg Instytut Badania 
W wywiadzie Izy Klementowskiej, Czego sie wstydzi Polak? ${ }^{54}$ respondenci wymieniają z krótkim uzasadnieniem, jako przyczyny wstydu:

- biedę, materialne ubóstwo ujawnione w towarzystwie lub jako upokorzenie podczas zakupów;

- nagość związaną z seksem, masturbację, marzenia seksualne i erotyczne, w tym nieadekwatne do wieku lub indywidualnie pojmowanej normy;

- $\quad$ piętnujące choroby, utratę kontroli nad fizjologią, niesamodzielność w upośledzeniu, zaburzenia pamięci społecznej, objawy starości, nadwagę, ginekomastię (u młodych mężczyzn);

- pochodzenie społeczne (ze środowiska nie wielkomiejskiego), porównania cywilizacyjne miasto - wieś, narodowość;

- brak empatyczności: zaniedbanie starych rodziców, nieudzielenie pomocy, obrzydzenie wobec pacjentów;

- $\quad$ porażkę biznesową;

- $\quad$ braki znajomości kultury;

- kłamstwa polityków;

- niezdolność do porzucenia męża tyrana;

- decyzję o bezdzietności.

Wątki te powtarzają się w innych wypowiedziach i wyliczankach, uzupełnione o: długi, impotencję, brak znajomości języków obcych, niskie wyksztalcenie ${ }^{55}$, utratę pracy, pobyt w więzieniu, kradzież, kierowanie autem w stanie nietrzeźwości (sic!) ${ }^{56}$; niską kulturę i obyczaje polityczne, chamstwo, homofobię ${ }^{57}$, spóźnianie, zapominanie i gubienie przedmiotów, defekty stroju (np. rozpięty rozporek, plamy), niekontrolowane, niewspółmierne i nieadekwatne do sytuacji reakcje emocjonalne ${ }^{58}$.

Jest prawdopodobne, że część społeczeństwa uzupełniłaby tę listę o: brak wiary w Boga, brak patriotyzmu i poczucia przynależności narodowej, seksualizację dzieci, odmienności psychoseksualne (LGBT), rozpad tradycyjnej rodziny, niewierność, rozwody, zmianę ról i wartości społecznych, cywilizację śmierci (aborcję i antykoncepcję) i zapewne inne społeczne „przewiny”.

Opinii Homo Homini; B. Tumiłowicz, Czego najbardziej się wstydzimy w historii Polski? „Przegląd” 14.11.2004.

54 I. Klementowska, Czego się wstydzi Polak?, „Gazeta Wyborcza”, 28.11.2012.

${ }_{55}$ Czego się wstydzimy? 10 gtównych powodów do wstydu...

${ }^{56}$ Piersi, penis, zdrada? Nie, Polacy wstydza się...

57 M. Grudniewska, $Z$ czego sq dumni i czego sie wstydza czytelnicy Wyborczej...

${ }^{58}$ Jedzenie między zębami, rozpięty rozporek - ciag dalszy wstydliwej listy - http://zdrowie.gazeta. pl/Zdrowie/1,105912,12480464,15_najczestszych_powodow_wstydu_i_czerwienienia_sie.html; dostęp: 2019-01-20; A. Gumowska, Polaków powody do wstydu. „Newsweek, Styl Życia”, 05.01.2015. 
Historycy i socjolodzy dorzucaja ${ }^{59}$ : partyjniactwo przedkładane nad interes państwa, przegrane nieprzemyślane powstania, okupację Zaolzia i interwencję w Czechosłowacji, zgodę na politykę PZPR lub uczestnictwo w niej, nacjonalizm, targowicę, służbę zaborcy, volkslistę, antysemityzm (z wskazanymi przypadkami, np. Jedwabnego), nietolerancję, zacofanie, bezhołowie (w tym sejmowe), politykę względem kresów wschodnich, zabójstwo Mościckiego (zapewne także Pawła Adamowicza i Marka Rosiaka)... i inne zdarzenia zróżnicowane w zależności od kontekstu historycznego i politycznego.

Ewelina Adamczyk ${ }^{60}$ cytując celebrytkę, psycholożkę Brené Brown, uważaną za guru w sprawach wstydu ${ }^{61}$,wymienia „kategorie wstydu”, dotyczące:

- wyglądu,

- $\quad$ statusu zawodowego i materialnego,

- rodzicielstwa,macierzyństwa/ojcostwa,

- rodziny/pochodzenia,

- $\quad$ stanu zdrowia,

- uzależnień,

- $\quad$ seksu,

- procesu starzenia się,

- wyznania,

- traumatycznych doświadczeń,

- $\quad$ wpływu na nasze życie stereotypów i etykietek.

Wspólnym mianownikiem wymienianych przyczyn wstydu wydaje się być naruszenie intymności, ujawnione impulsywne reakcje emocjonalne, naruszenie norm obyczajowych, „słabość woli” (np. wobec uzależnień) i w konsekwencji negatywny obraz/ocena podmiotu w porównaniach społecznych. Dla przyczyn wstydu istotny jest zatem społeczny i memetyczny punkt odniesienia.

Poza negacją wymienionych wartości, literacko zdefiniowaną cechą bezwstydu i przyczyną śmierci wstydu jest obłuda. Obserwowana w przekazie medialnym obłuda dotyczy - szczególnie u prominentnych osób - sprzeczności głoszonych ideałów z rzeczywistym zachowaniem. Ujmuje to schopenhauerowskie „A czy drogowskaz musi pójść do miasta?”62. Bezwstydna obłuda przejawia się

59 B. Tumiłowicz, Czego najbardziej się wstydzimy w historii Polski? „Przegląd” 14.11.2004.

60 E. Adamczyk, Czym jest wstyd? „Dzieci są ważne” 2019, on-line.

61 B. Brown, Shame Resilience Theory: A Grounded Theory Study on Women and Shame. "Families in Society: The Journal of Contemporary Social Services", SAGE Journals 2006, no 87(1), pp. 43-52.Shame Resilience Theory by Brené Brown - https://www.habitsforwellbeing.com/ shame-resilience-theory/; [dostep z dnia: 01.07.2019].

62 Także jako: „Drogowskaz nie musi iść w kierunku, który wskazuje”, „Drogowskaz 
szczególnie w kwestiach seksualności, celibatu, gromadzenia majątku i deklarowanego ubóstwa, sprawiedliwości, praworządności, uczciwości i nepotyzmu, a także w zderzeniu deklaracji miłości i przemocy rodzinnej. Bez trudu można znaleźć adekwatne przykłady.

\section{Obszary relacji psychicznych powodujące wstyd - synteza:}

- Sfera urogenitalna, analna (aboralna) rzadziej oralna: czynności fizjologiczne ze szczególnym naciskiem na seksualność, w tym: nagość w niekontrolowanej sytuacji społecznej;

- Niesprawność fizyczna i psychiczna, w szczególności uwłaczające objawy choroby, niepełnosprawności i starzenia się;

- Odmienność - odbieganie od normy społecznej pod względem fizycznym, psychicznym oraz zachowania typowego dla grupy odniesienia, w tym także: pochodzenie społeczne;

- Bieda i objawy niedostatku;

- Niewiedza w towarzystwie oceniającym oraz braki obycia kulturalnego (coraz rzadziej);

- Złamanie norm obyczajowych, towarzyskich i (niektórych) prawnych;

- Naruszenie intymności podmiotu;

- Uzależnienia - „słabość woli”;

- Ujawnione impulsywne reakcje emocjonalne, wtym: wzruszenie, strach, miłość, empatia, impulsywne reakcje agresywne, przemoc;

- Negatywny obraz/ocena podmiotu w porównaniach społecznych (jako uogólnienie).

\section{Źródła bezwstydu}

Analizę społecznej śmierci wstydu oprzeć można na modelowych sytuacjach, w których objawia się zanik wstydu. Zaliczyć do nich można m.in. reality show takie jak: Big Brother, W ukrytej kamerze, Matura to bzdura, programy w formule „talent show”, akceptacja działalności paparazzi, autoprezentacje w portalach społecznościowych, modowych, randkowych, autoprezentacje jackass. Zjawiska bullyingu, cyberbullyingu i sextingu wskazują, że nader często osoby impulsywnie lub łatwowiernie rezygnujące z ochrony intymności, z czasem doznają z tego powoduwstydu i upokorzenia.

Poszukując przyczyn społecznej śmierci wstydu można postawić kilka hipotez roboczych, prowizorycznie tytułując je jako: 1) łatwość i taniość bzdury;

stoi i wskazuje drogę, lecz sam nią nie podąża” ; za: https://pl.wikiquote.org/wiki/Arthur_ Schopenhauer (Inne) [dostep z dnia: 01.07.2019]. 
2) demistyfikacja wzorców; 3) dewaluacja edukacji i kultury; 4) błąd adresu; 5) długie dojrzewanie mądrości.

\section{Hipoteza I: Łatwość i taniość bzdury}

Mechanizm powodujący zanik wstydu w tym przypadku ma charakter memetyczny. Wynika on z konkurencji między wzorcami (memami, przekazami) trudnymi i przekazami banalnymi, wręcz prymitywnymi. Jest to w znacznej mierze wynik komercjalizacji przekazu społecznego i marginalizacji wpływu tzw. inteligencji. Zjawisko to analizuje m.in. Frank Furedi w Gdzie sie podziali wszyscy intelektualiśc ${ }^{63}$. Jako przyczyny zaniku szacunku dla głębokiej wiedzy i kompetencji proponuje on utylitaryzm i komercjalizację („gospodarka oparta na wiedzy”?), a także relatywizację wiedzy i nauki, która stała się, „niedemokratycznie” i „niepoprawnie politycznie”, za trudna dla przeciętnego odbiorcy. Konsekwencją prowadzącej do tego manipulacji społecznej jest pozorne równouprawnienie każdego poglądu i twierdzenia oraz brak wstydu lub co najmniej refleksji z powodu niewiedzy (np. „ja tam matematyki nie lubię"). Kulturowym i paranaukowym źródłem takiego bezwstydu jest pozorne przyzwolenie, uzasadnione „ludowym” - populistycznym - rozumieniem postmodernizmu. Zasadność różnorodności i uwarunkowanie kontekstowej interpretacji świata zostało tu potraktowane jako równoprawność wiedzy i niewiedzy oraz dopuszczalność sprzecznych praw i bezprawia. W jakimś stopniu wiąże się to z kryzysem demokracji - trudem respektowania różnorodności w granicach wolności innych ludzi.

Skutkiem jest zjawisko, które można byłoby określić, jako właśnie „łatwość i atrakcyjność bzdury” lub „e-sancta stupiditas w Nowym Wspaniałym Świecie” świecie mediów, w tym mediów społecznych i elektronicznych. Ruchy antyszczepionkowe, chem trails ${ }^{64}$, cudowne terapie (hyperoksygenoterapia, chelatoterapia, hydrokolonoterapia), skrajnie upraszczający sprzeciw wobec GMO, ignorancja ekonomiczna i wiele innych mogą być przykładami. W ujęciu informatycznym i komunikacji społecznej wyraża się to liczbą otwarć, lajków, komentarzy i przekazywania dalej informacji naukowej i pseudonaukowej (hoaxu) przez użytkowników internetu. Różnica w nasileniu propagacji osiąga poziom co najmniej jednego rzędu wielkości (dziesięciokrotności) na korzyść bzdur ${ }^{65}$. (Lies spread faster than the truth).

63 F. Furedi, Gdzie się podziali wszyscy intelektualiści, przeł. K. Makarczuk, Warszawa 2008.

64 M. Rotkiewicz, Wstrzasajaca teoria smug na niebie „Polityka” 2015, nr 13.

65 A. Bessi, M. Coletto, G.A. Davidescu, A. Scala, G. Caldarelli, W. Quattrociocchi, Science vs Conspiracy: Collective Narratives in the Age of Misinformation, "PLOS One" 2015. 
Ramka 1. O FALSZYWEJ WIEDZY, BEZWSTYDZIE JEJ SZERZENIA i RÓŻNICACH POGLĄDÓW - wybrane źródła

T. Ulanowski, Fake newsy rozchodza się szybciej i dalej niż prawda. I to nie wina internetowych botów - ustalili naukowcy, „Gazeta Wyborcza”, dodatek „Nauka” 10.03.2018.

A. Dryjańska, Wraz z epoka smartfonów i smartwatchów wielkimi krokami nadchodzi ciemność. Smartśredniowiecze, „Gazeta Wyborcza” 05.01.2019.

T. Targański, Handlarze zwatpienia. Żyjemy w wieku ignorancji, „Gazeta Wyborcza” 23.01.2018.

A. Bessi, M. Coletto, G. Alexandru Davidescu, A. Scala, G. Caldarelli,

W. Quattrociocchi, Science vs Conspiracy: Collective Narratives in the Age of Misinformation, "PLOS One"2015, February 23, DOI: 10.1371/journal.pone.0118093.

Streszczone, jako: „Nauka kontra teorie spiskowe: zbiorowe narracje w epoce dezinformacji” Wstrzasajaca teoria smug na niebie, Marcin Rotkiewicz, „Polityka” 2015, nr 32.

S. Vosoughi, D. Roy, S. Aral, The spread of true and false news online, "Science" 2018, Vol. 359, Issue 6380, pp. 1146-1151; DOI: 10.1126/science.aap9559.

C.M. Joseph, J. Graham, J. Haidt, The End of Equipotentiality: A Moral Foundations Approach to Ideology-Attitude Links and Cognitive Complexity, "Psychological Inquiry" 2009, No. 20, pp. 172-176.

J. Graham, J. Haidt, B.A. Nosek, Liberals and Conservatives Rely on Different Sets of Moral Foundations, "Journal of Personality and Social Psychology" 2009, Vol. 96, No. 5, pp. 1029-1046.

J. Graham, J. Haidt, B.A. Nosek, The Moral Stereotypes of Liberals and Conservatives: Exaggeration of Differences across the Political Spectrum, "PLoS ONE"2012, No. 7(12), p. e50092. doi:10.1371/journal.pone.0050092.

J. Haidt, M.A. Hersh, Sexual Morality: The Cultures and Emotions of Conservatives and Liberals, "Journal of Applied Social Psychology" 2001, No. 31, 1, pp. 191-221.

B.G. Purzycki, C. Apicella, Q.D. Atkinson, E. Cohen, R.A. McNamara, A.K. Willard, D. Xygalatas, A. Norenzayan, J. Henrich, Moralistic gods, supernatural punishment and the expansion of human sociality, "Nature" 2016, Feb 18;530(7590), pp. 327-230. doi: 10.1038/nature16980. Epub 2016 Feb 10.

B.G. Purzycki , C.T. Ross, C. Apicella, Q.D. Atkinson, E. Cohen, R.A. McNamara, A.K. Willard, D. Xygalatas, A. Norenzayan, J. Henrich, Material security, life history, and moralistic religions: A cross-cultural examination, "PLoS One" 2018, 2018https:// doi.org/10.1371/journal.pone.0193856.

\section{Hipoteza II: Demistyfikacja wzorców wysokich}

Niezależnie od niedających się zanegować pozytywów i zdobyczy demokracji (egalité, fraternité, liberté), zrównanie (bezcenne i pozorne niestety, gdy chodzi status majątkowy ludzi ${ }^{66}$ ) powoduje demistyfikację wzorców kultury wysokiej,

66 Oxfam International, Inequality (2018) - https://www.oxfam.org/en/tags/inequality 
w tym kultury zachowania. Oczywiście, zasadny jest zarzut, że elitarne wzorce kultury były fałszywe i pruderyjne. W demistyfikacji istotną rolę odgrywają twórcy kultury i dziennikarze. Ci ostatni nagłaśniając bieżące skandale obyczajowe jako negację wzorców zachowania. Ilustracją demistyfikacji moga być np. filmy Filipa Bajona Magnat, Kamerdyner i szerzone powszechnie plotki z intymnego życia „wyższych sfer” - celebrytów.

Napędzaną tymi wzorcami rezygnację z intymności - bezwstyd ilustrujący „śmierć wstydu” - dokumentuje Wikipedia (2019), wyliczając 139 programów typu reality show. Wzorcowy Big brother w roku 2001 budził zainteresowanie ok. $10 \mathrm{mln}$ widzów w Polsce. Podobnie działają programy typu „talent show” (np. Mam talent), programy lifestylowe. Intrygująca zapewne byłaby statystyka castingu do takich programów. Swój wkład mają także programy publicystyczne z udziałem odbiorców. Abstrahując od ambicji, kompetencji i jakości pracy twórców programów, takich jak: Szkto kontaktowe (TVN), W tyle wizji (TVP), Za, a nawet przeciw (III PR), dopuszczają one niejednokrotnie żenujące wypowiedzi rozemocjonowanych widzów i słuchaczy.

Być może za wcześnie lub w złą porę pogrzebano filistra i dulszczyznę, których zombie wracają. Za wcześnie też Gombrowicz i Mrożek stali się jedynie maturalnymi wzorcami prześmiewcy, a Boy-Żeleński zniknął z kulturalnego i społecznego obiegu.

Globalizacja komunikacji i kultury oraz związany z postępem rozpad tradycyjnych więzi rodzinnych i plemienno-wioskowych odcisnął się na strukturze relacji i ról społecznych, zaburzając (jak się wydaje naturalne) ewolucyjnie ukształtowane struktury hierarchiczne scharakteryzowane liczbami Dunbara ${ }^{67}$. Świat zmalał ${ }^{68}$ stwarzając iluzje, że każdy może zaistnieć, jako osoba będąca wzorcem dla pozostałych 7,6 miliarda ludzi. Pozorna łatwość zaistnienia w czasie „swoich 5 minut" może być przyczyną motywacji do zachowań skutkujących śmiercią wstydu. Nie jest to zjawisko nowe. Odnosi się bowiem do niego Liber generationis plebeanorum (Ksiega rodów plebejskich) Waleriana Nekandy Trepki z roku 1626.

Prowokująca śmierć wstydu - bezkompromisowa walka nie tylko o swoje 5 minut, ale i realne stanowiska i władzę - przybiera szczególnie dramatyczny wyraz w polityce. Bez trudu można mnożyć przykłady skompromitowanych i zawstydzonych polityków, liczących na amnezję i głupotę wyborców.

[dostep z dnia: 01.07.2019]; Oxfam International, Public Good Or Private Wealth?(2019) - https:// www.oxfam.org.nz/reports/public-good-or-private-wealth [dostep z dnia: 01.07.2019].

${ }^{67}$ Dunbar's number - Wikipedia: https://en.wikipedia.org/wiki/Dunbar\%27s_number [dostep z dnia: 01.07.2019]; warto zwrócić uwagę, że - niezależnie od uwag krytycznych wzgledem koncepcji - liczby te zaczynają się od 1,5 i rosną w przybliżeniu jako ciąg kolejnych wyników mnożenia przez 3: 1,5; 5; 15; 50; 150; 500; $1500 ; \ldots$ itd.; R.A.Hill, R.I.M. Dunbar, Social network size in humans, "Human Nature" 2003, no 14 (1), pp. 53-72; E.I.M. Dunbar, Ilu przyjaciót potrzebuje cztowiek? Liczba Dunbara i inne wybryki ewolucji, przeł. D. Cieśla-Szymańska, Kraków 2019.

${ }^{68}$ Small World Experiment - Wikipedia: https://en.wikipedia.org/wiki/Small-world_ experiment (Small Word Theory) [dostep z dnia: 01.07.2019]. 
Ramka 2. WSTYD, WSTYDLIWOŚĆ I BEZWSTYD W PRASIE - wybrane źródła

Brat brud. Agnieszka Krzemińska, Polityka 4 listopada 2009

Coraz więcej wulgaryzmów w naszej mowie. Agnieszka Krzemińska, „Polityka” 27 sierpnia 2013

Europa przy stole. O rewolucjach kulinarnych w dziejach Europy opowiada Sebastianowi Dudzie dr Tessa Capponi-Borawska, 16 listopada 2012

Krótka historia bielizny i bikini. Agnieszka Krzemińska, „Polityka” 20 sierpnia 2013

Krótka historia pornografii. Adam Tomaszewski, Onet 2012-04-16

Naga broń. Aleksandr Tiranow, „Nezawisimaia Gazeta” 19.12.2003

Mowa ciata. Dariusz Łukasiewicz, „Polityka” 1 lutego 2011

Obrzydliwość cudzej gęby, czyli o zachowaniu się przy stole. Joanna Banaś, „GW” 31 grudnia 2018

Papirusowa pornografia. Agnieszka Krzemińska, „Archeologia. Polityka” 23.10.2002

Problem toaletowy. Historia papieru toaletowego. Joanna Banaś, „GW. Ale Historia” 01.02 .2016

Sprośny humor z antycznych toalet. Agnieszka Krzemińska, Polityka 8 stycznia 2019

Śmierdzacy problem. Wychodki, stawojki, latryny. Elżbieta Manthey, „GW” 12.07.2016

Seks bez sensu. Joanna Cieśla, Olga Podgórska [współpr.], „Polityka” nr 33 (3022)

Sekspiosenki Cypisa i Popka na YouTubie ogladaja dzieci z podstawówki. Prawnicy mówia, że to porno. Ludmiła Anannikova, „GW” 9 kwietnia 2018 05:59

Erotyka bez jezyka. Dlaczego nie umiemy o tym rozmawiać... Ewa Winnicka, „Polityka” 24.09.2003

Rozum wyklęty, zabobon święty. Kazimierz Bem, Jarosław Makowski, „Polityka” 3 października 2017

Chaos norm, chaos moralny. Serwis naukowy PR, 24.09.2003

Inteligencja zamilkta. Barbara Skarga, „GW”, 13-01-2006

Polscy uczniowie poniżej średniej. „GW” w internecie, PAP, 04-12-01 14:49

Kraków: studenci biją absolutne rekordy. Onet Kraków AAAPAP, PH, 09-07-09

Licencjat dla wszystkich, magisterka dla elit. Klaus Bachmann, prof. politologii Uniwersytetu Wrocławskiego,Gazeta Wyborcza. 19.06.2009; http://forum.gazeta. pl/forum/w,72,96857673,96857673,Licencjat_dla_wszystkich_magisterka_dla_elit. html

Po milczacym proteście radiowej „Dwójki”. Kilar: Wtadza nie lubi inteligencji. „Dziennik”, czwartek 9 lipca 2009 08:03

Groźne wygtupy. Astrid De Larminat, "Le Figaro” 17.03.2004 


\section{Hipoteza III: Dewaluacja edukacji}

Dewaluacja dobra elitarnego i ekskluzywnego, jakim przez wieki było zdobywane w trudzie wykształcenie i umiejętności,nastąpiła za sprawą łatwego i powszechnego dostępudo edukacji. Ta zdobycz demokracji, w imię populistycznie pojętej równości, uwolniła znaczną część zdobywających wiedzę od wysiłku i rygorystycznej oceny. Łatwy i powszechny dostęp do elitarnego dobra powoduje utratę wartości i jakości tego dobra oraz brak punktu - wzorca odniesienia wzorca wysokiej jakości. Dyskusyjna sprawą jest poziom - wysokość - tejże jakości.

Drogę do umasowienia i dewaluacji wykształcenia otworzyły obiecujące skądinąd projekty reform edukacji i proces boloński ${ }^{69}$. Ich założeniem było, że powszechne i ustawiczne kształcenie spowoduje maksymalizację udziału ludzi z wyższym wykształceniem. Przełożyć się to miało na użyteczną gospodarczo wiedzę, umiejętności wyższe kształconych, wzrost ich kompetencji społecznych i kulturalnych oraz dojrzałą osobowość, jako „edukacyjną wartość dodaną”. W konsekwencji rozkwitnie gospodarka oparta na wiedzy i nastapi okres powszechnej mądrości i szczęścia. Ta (sarkastyczna) charakterystyka ma swoje uzasadnienie w realiach. Jednym z głównych problemów systemu edukacyjnego jest obecnie motywowanie kształcącej się młodzieży do (bardziej efektywnej) pracy. Służą temu krótkoterminowe projekty edukacyjne, otwarcie szkół wyższych na uczniów szkół podstawowych, promowanie studiów według indywidualnych programów, coaching i tutoring. Edukacyjna wartość „odjęta” objawia się zaś syndromem Piotrusia Pana dotykającym młodych mężczyzn, zjawiskiem bambocioni, problemem zagospodarowania wykształconej młodzieży, tj. bezrobociem lub zatrudnieniem na stanowiskach poniżej aspiracji, nadreprezentacją kobiet zdających maturę i studiujących (na co żali się Philip Zimbardo ${ }^{70}$ ) i wreszcie demografią „wykształciuchów” - koniecznością zachęt do posiadania dzieci.

Te niejednoznaczne $\mathrm{w}$ interpretacji problemy są szeroko i krytycznie dyskutowane w prasie i opracowaniach naukowych i popularyzatorskich ${ }^{71}$. Jako sygnał ostrzegawczy może tu służyć treść wypowiedzi Krzysztofa Warlikowskiego w Europarlamencie ${ }^{72}$. Stwierdza on:

40 proc. Polaków nie rozumie tego, co czyta. Doszliśmy do dna. To zagraża całej

Europie i demokracji. Dzisiaj blisko 40 proc. Polaków nie rozumie tego, co czyta, a kolejne 30 proc. rozumie w niewielkim stopniu. Co dziesiąty absolwent szkoły

69 Np. R. Jeż, Proces boloński a system szkolnictwa wyższego w Polsce. (2013), s. 91-99; cejsh. icm.edu.pl/cejsh/.../9_R.Jez_Proces_bolonski_a_system_szkolnictwa...pdf $\left[\begin{array}{l}\text { dostep } \\ z\end{array}\right.$ dnia: 01.07.2019] lub: A. Kraśniewski, Proces boloński. To już dziesięć lat. Fundacja Rozwoju Systemu Edukacji, Warszawa 2009, http://czytelnia.frse.org.pl/media/proces_bolonski_FINAL.pdf [dostep z dnia: 01.07.2019].

70 N. Coulombe, Ph. Zimbardo, Gdzie ci mężczyźni? Warszawa 2015.

71 P. Łaszczyca, Kuna w kurniku i biologia nauczania, czyli o tym, jak neurodydaktyka wtacza sie do sporu o szkote. „Przegląd Pedagogiczny” 2016, nr 1 [13], s. 119-150.

72 Przemówienie Krzystofa Warlikowskiego w Europarlamencie- „F5”, 2018, - http://www.fpiec. $\mathrm{pl} / \mathrm{tu}$-i-teraz/przemowienie-krzysztofa-warlikowskiego-w-parlamencie-europejskim-ktorepowinniscie-przeczytac [dostep z dnia: 01.07.2019]. 
podstawowej nie potrafi czytać. Aż 10 mln Polaków (ok. 25 proc.) nie ma w domu ani jednej książki. Analfabetą funkcjonalnym jest co szósty magister w Polsce. 6,2 mln Polaków znajduje się poza kulturą pisma, czyli nie przeczytało NIC, nawet artykułu w brukowcu. 40 proc. Polaków ma problemy z czytaniem rozkładów jazdy czy map pogodowych.

Ofertę usług edukacyjnych na poziomie wyższym przedstawia młodym Polakom 429 uczelni wyższych $(2015)^{73}$. Niemcy, mające trzy razy więcej ludności, mają tylko 415 uczelni. W roku 2005 - roku szczytu - w Polsce studiowało ok. 2 mln studentów, co daje pięciokrotny wzrost liczby od roku 1990. W przedziale od roku 2005 do chwili obecnej studiuje ogółem ok. 50\% grupy wiekowej 20-25 lat, co stanowi ok. czterokrotny wzrost względem roku $1990^{74}$. W praktyce, wydając w ciągu 3 lat sześć razy po 1000 lub 1500 zł za semestr i 40 razy w roku uczestnicząc łącznie w ok. 360 godzinach zajęć, student może uzyskać tytuł licencjata jakiegoś kierunku kształcenia.

Polska kształci więcej absolwentów wyższych uczelni niż Wielka Brytania i USA ${ }^{75}$. Internet pełen jest memów o jakości uczelni i poziomie absolwentów.

Na tym tle nie budzą zdumienia (dramatyczne) dane na temat czytelnictwa, opublikowane przez Bibliotekę Narodowa w roku 2018 ${ }^{76}$.

\section{Hipoteza IV: Długie dojrzewanie mądrości i błędy adresowania}

Co wolno wojewodzie... ${ }^{77}$

Jeśli... jeśli zadaniem, celem lub skutkiem tworzenia i odbioru sztuki jest kształtowanie człowieka, a może raczej jego wrażliwości i zdolności poznawczych, to nie ma jednej sztuki dla wszystkich. Zatem sztuka... dla wszystkich czy nie dla każdego? Być może przyrodnik nie powinien wypowiadać się na temat sztuki. Współczesna sztuka jest bardziej niż we wcześniejszych epokach przezwyciężaniem ograniczeń i poszukiwaniem wolności. Sztuka zatem to przekraczanie granic wyrazu, uwalnianie „ducha”, poszukiwanie wolności, ogniskowanie uwagi, nowe spojrzenie, prawda o świecie albo tylko jedno z możliwych przybliżeń do prawdy, które można czasami zrozumieć dopiero po pokonaniu długiej drogi rozwoju w odbiorze sztuki. Nie każdy i w nie każdym okresie życia może mieć szanse na osiągnięcie zdolności do odbioru konkretnych form sztuki.

Przekraczanie granic sztuki konwencjonalnej, oswojonej przez większość ludzi, mogłoby być kolejną przyczyną śmierci wstydu, a także pomieszania pojęć

73 Statystyka za InnPoland - https://innpoland.pl/117487,w-polsce-dziala-429-uczelniwyzszych-to-sytuacja-patologiczna-mowia-eksperci-i-nawoluja-do-konsolidacji [dostęp: 01.07.2019]; także: https://rynekpracy.pl/monitory/ponad-450-szkol-wyzszych-w-polsce [dostęp: 01.07.2019].

74 Statystyki za portalem StudenckaMarka - https://www.studenckamarka.pl/serwis. php?s=73\&pok=1922 [dostep z dnia: 01.07.2019].

75 TOK FM, Polska_generuje_wiecej_absolwentow_wyzszych_uczelni, TOK FM, df, zsz 08.09.2010, 15:12; http://www.tokfm.pl/Tokfm/1,103085,8350495,Polska_generuje_wiecej_ absolwentow_wyzszych_uczelni.html [dostep z dnia: 01.07.2019].

76 Stan czytelnictwa w Polsce w roku 2017. Bibloteka Narodowa 2018. - https://www.bn.org. pl/aktualnosci/3497-stan-czytelnictwa-w-polsce---pelny-raport-do-pobrania.html[dostęp: 01.07.2019].

77 J. Krzyżanowski Mądrej gtowie dość dwie stowie, Warszawa 1975, T II, s. 74. 
oraz wartości. Byłby to wynik złego adresowania dzieł sztuki, albo złej ich propagacji. Kontrowersyjne dzieła (z niewielkim trudem można ich przywołać więcej), to często już klasyczne utwory, jak Fontaine Marcela Duchampa (Exposition of Independent; NY 1917), Merda d'artiste Pierro Manzoniego (Tate, 1961, sprzedane za 124,000 - przez dom aukcyjny Sothleby 23 maja 2007 r.). Nowe spojrzenie na bajkę Wilhelma i Jacoba Grimmów Muzykanci z Bremy niesie Love is forever Maurizio Catellana i Piramida zwierzat Katarzyny Kozyry (1993). Budzi kontrowersje rzeźba La nona ora Maurizio Catellana, przedstawiająca Jana Pawła II przygniecionego przez meteoryt. Niebezpiecznym przełamywaniem granic jest Święto wiosny Katarzyny Kozyry (2002) odwołujące się do Święta wiosny Igora Strawińskiego i Siergieja Diagilewa (1913). Zmusza ono do trudnej pracy, by zrozumieć, co artystka chciała przekazać, wykonując przed kamerą animację nagimi ciałami pensjonariuszy domu starców. Narusza delikatne normy trudna i wstydliwa prawda o seksualności Doroty Nieznalskiej w Pasji (2001). W sytuacji, gdy na temat obozów zagłady powiedziano już wszystko - do zanudzenia na śmierć - i zapomniano już wszystko, budzi oburzenie instalacja/happening Berek (w komorze gazowej Auschwitz) Artura Żmijewskiego (1999). A można jeszcze wspomnieć o zestawie klocków Lego. Obóz koncentracyjny Zbigniewa Libery.

Rodzi się pytanie, do kogo adresowane są te dzieła, jeśli większość ich nie rozumie i odrzuca z głośnym protestem, jako bezwstyd twórcy - artysty. $\mathrm{Z}$ pewnością nie są one łatwym przewodnikiem. Źle zrozumiane przełamywanie granic i budzenie wrażliwości może stać się dla niewyrobionego odbiorcy wzorem i pretekstem do uśmiercenia wstydu podczas wykonywania selfie ,ja przy piecu krematoryjnym w Auschwitz”. Ten konflikt ma może najmniejszy zasięg, ale jest też istotny, jako wyraz spotkania pokoleń.

Odrębnym problemem w korozji wstydu są komercjalne dzieła sztuki filmowej epatujące seksem i przemocą. Stosunkowo łagodnym przykładem może być Piéćdziesiąt twarzy Greya w reżyserii Sama Taylor-Johnsona (2015). Film ten epatował sadomasochistycznymi treściami znaczną część młodej publiczności, a jego efekt kulturotwórczy i psychologiczny wart jest zapewne pogłębionej obserwacji. Znacznie większy wkład w śmierć wstydu mogą mieć filmy pornograficzne i thrillery daleko odbiegające od np. żartobliwie zabarwionych erotyką treści Dekameronu Boccaccia.

\section{Wstyd końca}

Bezwstyd ignoracji i negacji jest groźny w sprawach istotnych dla funkcjonowania, a może nawet istnienia społeczeństw. Widać go w cynizmie wypowiedzi populistycznych polityków. Z rzadka towarzyszą mu uchwycone przez kamery objawy wstydu, jak w przypadku polityka, który w styczniu 2018 r. twierdził, że smog nie jest problemem. Wstyd wymaga wiedzy, empatii i czasami odwagi, gdy dotyczy spraw ważnych. 
Pewną niedogodnością bycia człowiekiem jest, że starzy, wykształceni, doświadczeni i obyci (w jakimś tam przynajmniej stopniu) ze światem i kulturą podlegają demencji i umierają ze swoją (nie)wiedzą i wstydem. Młodzi zaś muszą wszystko zdobyć od podstaw, popełniając te same błędy, co ich poprzednicy.

Przyjmując ewolucjonistyczną i memetyczną wizję komunikacji, społeczną śmierć wstydu i szerzenie się zachowań bezwstydnych można równocześnie rozpatrywać w kategoriach mechanizmów biologicznych i neurobiologicznych. Zachowania bezwstydne wydają się wymagać mniejszego nakładu pracy, mniejszej wiedzy i obycia kulturalnego. Zatem, sumarycznie, niższych kosztów adaptacji. Bezwstyd może doraźnie dostarczać silniejszego wzmocnienia emocjonalnego i większych doraźnych korzyści. Może to w krótkich okresach czasu sprzyjać szerzeniu się zachowań bezwstydnych, tak długo jak długo nie ujawnią się ich negatywne konsekwencje dla jednostki i całych społeczności. Długoterminowe, odroczone efekty bezwstydu mogą być trudne do pojęcia dla osób o ograniczonej wiedzy, osób zmanipulowanych ideologicznie lub osób o egoistycznych intencjach. Prawdopodobnie możliwe byłoby matematyczne modelowanie takich zależności z użyciem systemów Big Data. Jako model propagacji obłudy i bezwstydnego kłamstwa można przyjąć wielkie systemy i ideologie totalitarne lub np. wiktoriańską pruderię. Taktować je można jako systemy memetyczne odwzorowujące rzeczywistość w nieprawdziwy sposób. Przełamanie wzorców niesionych przez „bezwstydne” systemy wiązało się katastrofalnymi zjawiskami historycznymi lub obyczajowymi rewolucjami. Pociągało za sobą znaczne koszty społeczne i konieczność bolesnych przewartościowań w mentalności (systemach memetycznych - memepleksach) zarówno pojedynczych ludzi jak i społeczności. Prawdopodobnie dobrym modelem konkurencji wstydu i bezwstudu byłyby socjobiologiczne zasady altruizmu zwrotnego oraz ewolucyjnie stałej (puli) strategii zachowania. Badanie w tych kierunkach z konieczności zazębiać się będą z badaniami nad moralnością, ideologią i polityką.

\section{BibLIOGRAFIA}

Abu Ghraib torture and prisoner abuse, https://en.wikipedia.org/wiki/Abu_Ghraib_torture_ and_prisoner_abuse[dostęp 20.01.2019].

Adamczyk E., Czym jest wstyd? „Dzieci są ważne” 2019.

Baron-Cohen S., Leslie A.M., Frith U., Does the autistic child have a theory of mind?, "Cognition" 1985, no 21(1), pp. 37-46.

Baron-Cohen S., Precursors to a theory of mind: Understanding attention in others, (in) Natural theories of mind: evolution, development, and simulation of everyday mindreading, ed. A. Whiten, Oxford, UK Cambridge, Massachusetts1991, pp. 233-251.

Bekoff M., Can Dogs Experience Guilt, Pride, and Shame: Why Not? "PsychologyToday" 2013; 
https://www.psychologytoday.com/intl/blog/animal-emotions/201303/can-dogs-experience-guilt-pride-and-shame-why-not; [dostęp: 2018-12-20].

Bessi A., Coletto M., Davidescu G.A., Scala A., Caldarelli G., Quattrociocchi W., Science vs Conspiracy: Collective Narratives in the Age of Misinformation, "PLOS One" 2015, publ. February 23.

Biblia Tysiaclecia Online, 2003 [dostęp:20.01.2019].

Błachnio A., Identyfikacja wstydu, „Studia z psychologii w KUL” 2005, T. 12.

Brown B., Shame Resilience Theory: A Grounded Theory Study on Women and Shame. "Families in

Society: The Journal of Contemporary Social Services" SAGE Journals, 2006, no 87(1), pp. 43-52.

Budzyńska-Daca A., Wstyd - uczucie czy cnota? Dylematy etyki arystotelesowskiej w komentarzach Sebastiana Petrycego z Pilzna, w:Wstyd w kulturze 2. Kolokwia polsko-biatoruskie, red. E. Kosowska, G. Kurylenka, A. Gomóła, Katowice 2008, s. 119-130.

Bynum W.E., Artino A.R,. Uijtdehaage S., Webb A.M.B., Varpio L., Sentinel Emotional Events:

The Nature, Triggers, and Effects of Shame Experiences in Medical Residents, “Acad Med.” 2019, No. 94(1), pp. 85-93.

Coulombe N., Zimbardo Ph., Gdzie ci mężczyźni?, przeł. M. Guzowska, Warszawa 2015.

Czego się wstydzimy? 10 gtównych powodów do wstydu, http://tupacz.com/2013/01/czego-sie-wstydzimy-10-glownych-powodow-do-wstydu, [dostęp:20.01.2019].

Danieluk B., Konceptualizacja poczucia winy $i$ wstydu w ujeciu poznawczym i spotecznym, „Annales Universitatis Mariae Curie-Skłodowska, Lublin - Polonia” vol. XIX Sectio J, 2006, s. 71-86.

Darwin Ch., The Expression of the Emotions in Man and Animals, Chapter 13: Self-Attention, Shame, Shyness, Modesty; Blushing, New York 1872, pp. 309-346.

De France, K., Lanteigne D., Glozman J., Hollenstain T., A New Measure of the Expression of Shame: The Shame Code, "Journal of Child \& Family Studies” 2017, No. 26(3), pp. 769-780.

Dolezal L.,Shame, Vulnerability and Belonging: Reconsidering Sartre's Account of Shame, "Human Studies" 2017, No. 40(3), pp. 421-438, First Online: 06 June 2017

Dunbar E.I.M., Ilu przyjaciót potrzebuje cztowiek? Liczba Dunbara i inne wybryki ewolucji, przeł.

D. Cieśla-Szymańska, Kraków 2019.

Dunbar R.I.M., Nowa historia ewolucji cztowieka, przeł. B. Kowalczyk, Kraków 2013.

Dunbar's number, Wikipedia: https:/ / en.wikipedia.org/wiki/Dunbar\%27s_number [dostęp: 20.01.2019].

Dvash J.J., Shamay-Tsoory S.G., Theory of Mind and Empathy as Multidimensional Constructs. Neurological Foundations, “Top Language Disorders” 2015, no 34(4), pp. 282-295.

Frankl V.E., Cztowiek w poszukiwaniu sensu, przeł. A. Wolnicka, Warszawa 2018.

Furedi F., Gdzie sie podziali wszyscy intelektualiści, przeł. K. Makarczuk, Warszawa 2008.

Genga J.J., Vossel S., Re-evaluating the role of TPJ in attentional control: Contextual updating?

"Neuroscience and Biobehavioral Reviews" 2013, No. 37, pp. 2608-2620.

Gęba a twarz i pupizm, www.gombrowicz.net [dostęp:20.01.2019].

Gomóła A., Przeciw naturze i kulturze. Transseksualizm a wstyd, w: Wstyd w kulturze 2. Kolokwia polsko-biatoruskie, red. E. Kosowska, G. Kurylenka, A. Gomóła, Katowice 2008, s. 40-69.

Grudniewska M., Z czego sa dumni i czego sie wstydza czytelnicy Wyborczej, „Gazeta Wyborcza” 16 maja 2018; [dostęp:20.01.2019]. 
Gumowska A., Polaków powody do wstydu, „Newsweek, Styl Życia” 05.01.2015.

Hickok G., Mit neuronów lustrzanych, przeł. A. Machniak, K. Cipora, Kraków 2016.

Higgins N., Shame on You: The Virtuous Use of Shame in the Aristotle's Nicomachean Ethics, "Expositions" 2015, No. 9(2), pp. 1-15.

Hill R.A., Dunbar R.I.M., Social network size in humans, "Human Nature" 2003, No. 14 (1), pp. 53-72.

Izard C.E., Emotion Theory and Research: Highlights, Unanswered Questions, and Emerging Issues, "Annual Review of Psychology" 2009, No. 60, pp. 1-25.

Jedzenie między zębami, rozpiety rozporek - ciag dalszy wstydliwej listy, http://zdrowie.gazeta.pl/ Zdrowie/1,105912,12480464,15_najczestszych_powodow_wstydu_i_czerwienienia_sie. html,[dostęp:20.01.2019].

Jeż R., Proces boloński a system szkolnictwa wyższego w Polsce, 2013, s. 91-99; cejsh.icm.edu.pl/ cejsh/.../9_R.Jez_Proces_bolonski_a_system_szkolnictwa....pdf [dostęp: 20.01.2019].

Klementowska I., Czego się wstydzi Polak?, „Gazeta Wyborcza” 28 grudnia 2012; [dostęp: 20.01.2019].

Kozloski J., Closed-Loop Brain Model of Neocortical Information-Based Exchange, "Frontiers in Neuroanatomy" 2016,

Kraśniewski A., Proces boloński. To już dziesięć lat, Fundacja Rozwoju Systemu Edukacji, Warszawa 2009; http://czytelnia.frse.org.pl/media/proces_bolonski_FINAL.pdf [dostęp: 20.01.2019].

Kwiatek Ł., Intencjonalność, czyli co odróżnia Szekspira od szympansa, „GraniceNauki.pl” (online) 09.07.2013; https://www.granicenauki.pl/intencjonalnosc-czyli-co-odroznia-szekspira-od-szympansa-25965 [dostęp: 20.01.2019].

Leedom L., Sociopaths and Psychopaths: Have you no shame? (sci - med-blog) lovefraud.com; 2007, https:/ / lovefraud.com/sociopaths-and-psychopaths-have-you-no-shame/ [dostęp: 20.01.2019].

Lewis M., Haviland-Jones J.M., Psychologia emocji, przeł. M. Kacmajor i in., Gdańsk 2005, s. 765.

Lövheim H., A new three-dimensional model for emotions and monoamine neurotransmitters, "Medical Hypotheses" 2012, No. 78, pp. 341-348.

Łaszczyca P., Kuna w kurniku i biologia nauczania, czyli o tym, jak neurodydaktyka wtacza się do sporu o szkote, „Przegląd Pedagogiczny” 2016, nr 1 [13],s. 119-150.

Łaszczyca P., Memy w pamięci: jak wyśledzić memy w mózgu, „Teksty z ulicy. Zeszyt memetyczny” 2017, rr 18, s. 11-42.

Mahony M., Titanic vs. Lusitania: Time Determined Who Survived, "LiveScience" March 01, 2010; https://www.livescience.com/10953-titanic-lusitania-time-determined-survived. html[dostęp: 20.01.2019].

Miceli M., Castelfranchi Ch., Reconsidering the Differences Between Shame and Guilt, "Europe's Journal of Psychology" 2018, ejop.psychopen.eu pp. 1841-0413.

Michl P., Meindl Th., Meister F., Born Ch., Engel R.R., Reiser M., Hennig-Fast K., Neurobiological underpinnings of shame and guilt: a pilot fMRI study,SCAN 214, No. 9, pp. 150-157.

Młynarska-Jurczuk A., Wstyd jako emocja ucieleśniona - twarz, ciato i role ptciowe w procesie spotecznej konsukcji wstydu, „Dyskursy Młodych Andragogów (Zielona Góra)” 2016, nr 17, s. 367-369.

Morrison A.P., Working with shame in psychoanalytic treatment, "J Am Psychoanal Assoc." 1984, No. 32(3), pp. 479-505. 
Muris P., Meesters C., Heijmans J., van Hulten S., Kaanen L., Oerlemans B., Stikkelbroeck T., Tielemans T., Lack of guilt, guilt, and shame: a multi informant study on the relations between selfconscious emotions and psychopathology in clinically referred children and adolescents, "European Child \& Adolescent Psychiatry" 2016, No. 25, pp. 383-396.

Najbardziej wstydliwe pytania jakie macie w gtowie,https:/ / m-forum.pl/topic/48811-najbardziej-wstydliwe-pytania-jakie-macie-w-glowie/[dostęp: 20.01.2019].

O'Hare R., Shame isn't necessarily a bad thing! Emotion evolved as a 'survival mechanism' to protect us from damaging friendships, "DailyMail" 2 March 2016; https://www.dailymail.co.uk/sciencetech/article-3472937/Shame-isn-t-necessarily-bad-thing-Emotion-evolved-survivalmechanism-protect-damaging-friendships.html[dostęp: 20.01.2019].

Oxfam International, Inequality (2018),https://www.oxfam.org/en/tags/inequality dostęp: 20.06.2019].

Oxfam International, Public Good Or Private Wealth?, https://www.oxfam.org.nz/reports/ public-good-or-private-wealth[dostęp: 15.07.2019].

Patostream, https://pl.wikipedia.org/wiki/Patostream [dostęp: 19.02.2019].

Piersi, penis, zdrada? Nie, Polacy wstydza sie.., „Fakt” 24 kwietnia 2013, wg Instytut Badania Opinii Homo Homini, https://www.fakt.pl/wydarzenia/polska/czego-najbardziej-wstydza-sie-polacy/3hqh1yq; [dostęp: 20.01.2019].

Plutchik R., The Nature of Emotions: Human emotions have deep evolutionary roots, a fact that may explain their complexity and provide tools for clinical practice,"American Scientist" 2001, No. 89(4), pp. 344-350.

Posner J., Russell J.A., Peterson B.S., The circumplex model of affect: An integrative approach to affective neuroscience, cognitive development, and psychopathology, "Developmental Psychopathology" 2005, No. 17(3), pp. 715-734.

Premack D., Woodruff G., Does the chimpanzee have a theory of mind?'Behavioral and Brain Sciences" 1078, No. 1(4), pp. 515-526.

„Przeciw - czytamy, jest - pan poset Kurski. Dlaczego Pan ktamat?” „Newsweek” 07.09.2017.

Przemówienie Krzystofa Warlikowskiego w Europarlamencie, „F5” 2018, - http://www.fpiec.pl/tu-i-teraz/przemowienie-krzysztofa-warlikowskiego-w-parlamencie-europejskim-ktore-powinniscie-przeczytac[dostęp: 20.01.2019].

Pulcu E., Lythe K., Elliott R., Green S., Moll J.W., Deakin J.F., Zahn R., Increased Amygdala Response to Shame in Remitted Major Depressive Disorder, "PLoS ONE” 2014, No. 9(1), pp. e86900.

Raymond Ch.C., Shame And Virtue In Aristotle, "Oxford Studies in Ancient Philosophy” 2017, No. 53, pp. 111-161.

Raymond Ch.C., Shame and Virtue in Plato and Aristotle, Dissertation Presented to the Faculty of the Graduate School of The University of Texas at Austin in Partial Fulfillment of the Requirements for the Degree of Doctor of Philosophy, The University of Texas at Austin, May 2013, https://repositories.lib.utexas.edu/handle/2152/25184, pp. 11-151 (http://hdl.handle.net/2152/25184) [dostęp: 20.01.2019].

Retzinger S.M., Identifying Shame and Anger in Discourse. "American Behavioral Scientist" 1995, No. 38(8), pp. 1104-1113.

Rotkiewicz M., Wstrzasajaca teoria smug na niebie, „Polityka” 2015, nr 16.

Russell J. A., A circumplex model of affect, "Journal of Personality and Social Psychology" 1980, No. 39(6), pp. 1161-1178. 
Scheff Th.J., Shame and conformity: The deference-emotion system, „American Sociological Review” 1988, No. 53(3), pp. 395-406.

Scheff, T.J.,Socialization of emotions: Pride and shame as causal agents, in: "Research Agendas in the Sociology of Emotions", ed. T. Kemper, New York 1990, pp. 283.

Shame Resilience Theory by Brené Brown,https:/ / www.habitsforwellbeing.com/shame-resiliencetheory/[dostęp: 20.07.2019].

Small World Experiment, Wikipedia: https://en.wikipedia.org/wiki/Small-world_experiment (Small Word Theory).

Stan czytelnictwa w Polsce w roku 2017, Biblioteka Narodowa 2018, https://www.bn.org.pl/ aktualnosci/3497-stan-czytelnictwa-w-polsce--pelny-raport-do-pobrania.html [dostęp: 20.01.2019].

Statystykaza „InnPoland”,https:/ /innpoland.pl/117487,w-polsce-dziala-429-uczelni-wyzszych -to-sytuacja-patologiczna-mowia-eksperci-i-nawoluja-do-konsolidacji [dostęp:20.01.2019]; także:https:/ / rynekpracy.pl/monitory/ponad-450-szkol-wyzszych-w-polsce [dostęp: 20.01.2019].

Statystyki za portalem „StudenckaMarka”, https://www.studenckamarka.pl/serwis. php?s=73\&pok=1922 [dostęp: 20.01.2019].

Sznycer D., Tooby J., Cosmides L., Porat R., Shalvi Sh., Halperin E., Shame closely tracks the threat of devaluation by others, even across cultures, "Proceedings of the National Academy of Sciences" 2016, No. 113(10), 201514699.

Theory of emotion - https://en.wikipedia.org/wiki/Emotion [dostęp: 2019-01-18].

Titanic vs. Lusitania. Who survived and why, http://www.smithsonianmag.com/sciencenature/titanic-vs-lusitania-who-survived-and-why-24622866/\#CmSsRx1wXjS1jVuO.99 [dostęp: 20.01.2019].

TOK FM, Polska generuje więcej absolwentów wyżsych uczelni, TOK FM, df, zsz 08.09.2010, 15:12; http://www.tokfm.pl/Tokfm/1,103085,8350495,Polska_generuje_wiecej_absolwentow_ wyzszych_uczelni.html[dostęp:20.01.2019].

„Trwa walka z „patostreamerami”, bialystok.eska.pl/t-patostream-kanaly, 16 kwietnia 2018,[dostęp: 20.01.2019].

Tumiłowicz B. Czego najbardziej się wstydzimy w historii Polski?, „Przegląd” 14.11.2004; https:// www.tygodnikprzeglad.pl/czego-najbardziej-sie-wstydzimy-historii-polski/ [dostęp: 20.01.2019].

Waal F.B.M. de, Commiserating Mice, "Scientific American" 24 June 2007.

Waal F.B.M. de, Wiek empatii. Jak natura uczy nas życzliwości, przeł.Ł. Lamża, Kraków 2019.

Wężowicz-Ziółkowska D., Wstyd a władza (paradygmatów), w: Wstyd w kulturze 2. Kolokwia polsko-biatoruskie, red. E. Kosowska, G. Kurylenka, A. Gomóła, Katowice 2008, s. 15-31.

Woodruff C.Ch., Reflections Of Others And Of Self: The Mirror Neuron System's Relationship To Empathy, chapter 6, in:The Neuroscience of Empathy, Compassion, and Self-Compassion, Elsevier 2018, pp. 157-187.

Yinghua L., The Phenomenology of Shame: A Clarification in Light of Max Scheler and Confucianism. "Continental Philosophy Review" 2018, No. 51 (4), pp. 507-525.

Zahavi D., Self, consciousness, and shame, in:The Oxford Handbook of Contemporary Phenomenology, New York 2012.

Zaslav M., Narcissism: The Shame-Negating Personality, “The Neuropsychoterapist”2017, No. 
5(2), pp. 17-18; https://www.thescienceofpsychotherapy.com/narcissism-the-shamenegating-personality/ [dostęp: 10.07.2019].

Zimbardo P., Haney C., Banks W.C., Jaffe D., The Stanford prison experiment. (Report), 1971; https://web.stanford.edu/dept/spec_coll/uarch/exhibits/Narration.pdf [dostęp: 10.07.2019].

\section{Nota o autorze}

Piotr Łaszczyca - doktor habilitowany, pracownik Wydziału Biologii i Ochrony Środowiska Uniwersytetu Śląskiego, specjalista fizjologii zwierząt i ekotoksykologii, prowadził badania w zakresie neurobiologii, fizjologii pracy, ekotoksykologii, zarządzania środowiskiem przyrodniczym. Wykładowca przedmiotów: biologiczne podstawy zachowania człowieka i zwierząt, biologiczne podstawy rozwoju i wychowania, ekologia człowieka, fizjologia pracy, zarys neurokognitywistyki. Inteligencja, jej memy oraz fizyka i mechanika. Autor m.in. artykułów: Memy w pamięci: jak wyśledzić memy w mózgu (2017), Mózg w drodze do dojrzałości (2016), Kuna w kurniku i biologia nauczania (2016), Zaśmiecony umyst (2003).

\section{About the author}

Piotr Łaszczyca - employed at Faculty of Biology and Environmental Protection, animal physiologist, conducted research in neurobiology, work physiology, ecotoxicology and environmental management. Lecturer of biological basis of human and animal behavior, human ecology, work physiology and principles of neurocognitivistics. Author of popular articles: Memy w pamięci: jak wyśledzić memy w mózgu (2017), Mózg w drodze do dojrzatości (2016), Kuna w kurniku i biologia nauczania (2016), Zaśmiecony umyst (2003). 